\title{
Design of Iridium N-Heterocyclic Carbene Amino Acid Catalysts for Asymmetric Transfer Hydrogenation of Aryl Ketones
}

\author{
Chad M. Bernier (D) and Joseph S. Merola *
}

Department of Chemistry, Virginia Tech, Blacksburg, VA 24061, USA; chadb@vt.edu

* Correspondence: jmerola@vt.edu

Citation: Bernier, C.M.; Merola, J.S Design of Iridium N-Heterocyclic Carbene Amino Acid Catalysts for Asymmetric Transfer Hydrogenation of Aryl Ketones. Catalysts 2021, 11, 671. https://doi.org/10.3390/ catal11060671

Academic Editors: Kotohiro Nomura, Takeshi Ohkuma, Martin Kotora, Alfonso Grassi, Victorio Cadierno, Carmine Capacchione, Ken-ichi

Fujita, Kei Manabe, Raffaella

Mancuso, Armando Pombeiro, Fabio Ragaini and Carl Redshaw

Received: 24 April 2021

Accepted: 21 May 2021

Published: 24 May 2021

Publisher's Note: MDPI stays neutral with regard to jurisdictional claims in published maps and institutional affiliations.

Copyright: (c) 2021 by the authors. Licensee MDPI, Basel, Switzerland This article is an open access article distributed under the terms and conditions of the Creative Commons Attribution (CC BY) license (https:// creativecommons.org/licenses/by/ $4.0 /)$.

\begin{abstract}
A series of chiral complexes of the form $\operatorname{Ir}(\mathrm{NHC})_{2}(\mathrm{aa})(\mathrm{H})(\mathrm{X})(\mathrm{NHC}=\mathrm{N}$-heterocyclic carbene, aa $=$ chelated amino acid, $X=$ halide) was synthesized by oxidative addition of $\alpha$-amino acids to iridium(I) bis-NHC compounds and screened for asymmetric transfer hydrogenation of ketones. Following optimization of the reaction conditions, $\mathrm{NHC}$, and amino acid ligands, high enantioselectivity was achieved when employing the $\operatorname{Ir}(\mathrm{IMe})_{2}(\mathrm{~L}-\mathrm{Pro})(\mathrm{H})(\mathrm{I})$ catalyst (IMe = 1,3-dimethylimidazol-2-ylidene), which asymmetrically reduces a range of acetophenone derivatives in up to $95 \%$ enantiomeric excess.
\end{abstract}

Keywords: iridium; N-heterocyclic carbene; amino acid; asymmetric transfer hydrogenation

\section{Introduction}

The production of optically pure alcohols is is an essential transformation in organic synthesis, with particular relevance in the pharmaceutical, agrochemical, and fine chemical industries [1]. A common and practical approach to these compounds in academia and industry is the enantioselective reduction of ketones to chiral alcohols using homogeneous transition metal catalysts (Scheme 1) [2]. The synthesis of an optically pure alcohol via addition of $\mathrm{H}_{2}$ across the $\mathrm{C}=\mathrm{O}$ bond of a prochiral ketone in the presence of a chiral catalyst is known as asymmetric hydrogenation. This process is referred to as asymmetric transfer hydrogenation (ATH) when it is carried out using a hydrogen source other than $\mathrm{H}_{2}$, typically in the presence of a suitable hydrogen donor molecule and base.

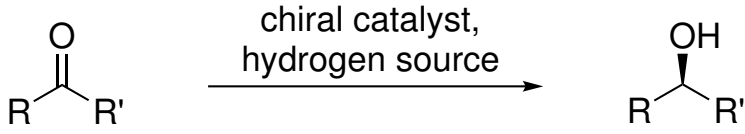

Scheme 1. Transition metal catalyzed enantioselective reduction of ketones to chiral alcohols.

The major breakthrough in asymmetric transfer hydrogenation came in 1995 from Noyori and coworkers, with the synthesis of a ruthenium(II) arene catalyst featuring a chiral mono-tosylated DPEN ligand (Figure 1) [3-6]. The catalyst is highly active for enantioselective reduction of a range of aromatic ketones, generating the chiral alcohol products in up to $99 \%$ enantiomeric excess (ee). Noyori's system operates through an outersphere transfer hydrogenation mechanism in which the substrate does not bind directly to the metal center, with hydrogen transfer instead occurring via a highly ordered cyclic transition state between the catalyst and substrate [7-11]. This concept of a "metal-ligand bifunctional catalyst" [12-16] is widely used today in a vast number of hydrogenation systems, and numerous related chiral catalysts and ligands have been investigated for ATH. Many successful contemporary ATH catalysts often employ noble metals such as ruthenium, rhodium, and iridium in combination with a variety of chiral ligands, the most common being derived from diamines, amino alcohols, and diphosphines [17-23]. 


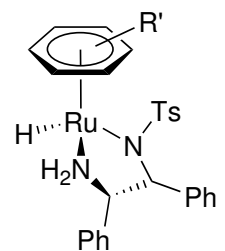

(A)

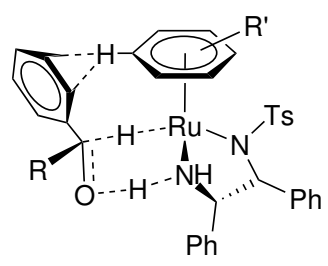

(B)

Figure 1. (A) Structure of Noyori's ruthenium arene TsDPEN active catalyst for ATH of ketones. (B) Noyori's catalyst operates through a concerted outer-sphere mechanism where the substrate does not directly bind to the metal center. For aryl ketone substrates, the transition state is stabilized by $\mathrm{CH} / \pi$ interactions between the catalyst and ketone.

While ATH is well-studied, ligands frequently used in these transformations, such as TsDPEN or chiral amino alcohols, are often synthetically challenging and not particularly cost-effective. Since many successful ATH catalysts make use of rather expensive noble metals, the incorporation of cheaper chiral ligands would be highly desirable. Amino acids are an intriguing class of ligand candidates due to their vast array of structural diversity and relatively low cost ( $\sim \$ 1$ per gram). A number of studies have demonstrated the promising potential of transition metal catalysts featuring amino acid ligands for asymmetric transfer hydrogenation [24-32], including rhodium and iridium $\mathrm{Cp}^{*}$ amino acid catalysts previously developed by the Merola group [33,34].

$\mathrm{N}$-Heterocyclic carbenes (NHCs) have also emerged as ligands of interest for asymmetric transformations due to their their strong $\sigma$-donor properties, inertness, and vast structural tunabilility [35,36], allowing for the design of various unique chiral scaffolds [37-39]. Although noble metal NHC complexes generally display excellent activity for catalytic transfer hydrogenation, examples of highly enantioselective catalysts of this type remain relatively scarce [2,40-43]. Iridium NHC complexes have been extensively studied for ATH of ketones; however, the majority of these catalysts employ synthetically challenging chiral NHC ligands that generate the alcohol products in only low to moderate enantiomeric excess (Figure 2) [44-52].
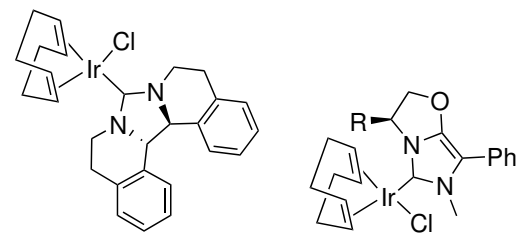

$$
\mathrm{R}={ }^{i} \mathrm{Pr},{ }^{\mathrm{s}} \mathrm{Bu},{ }^{i} \mathrm{Bu}
$$

$41 \%$ ee

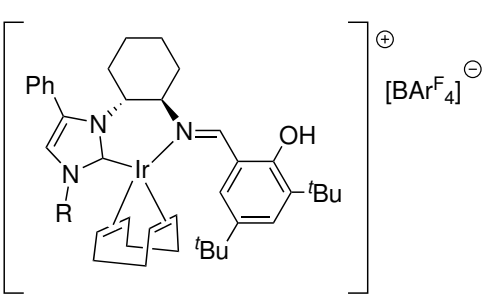

$\mathrm{R}=\mathrm{Et},{ }^{i} \mathrm{Pr}, \mathrm{Bn}, \mathrm{CHPh}_{2}$

$43 \%$ ee

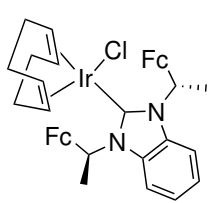

$53 \%$ ee

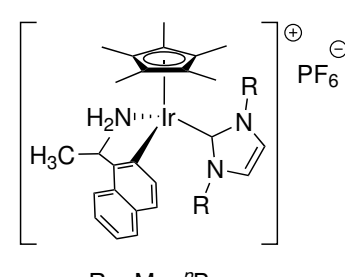

$\mathrm{R}=\mathrm{Me},{ }^{\mathrm{n}} \mathrm{Bu}$

$58 \%$ ee

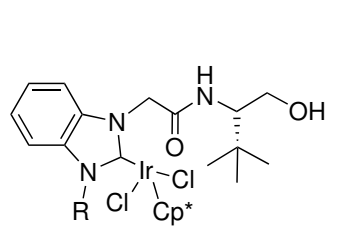

$\mathrm{R}=\mathrm{Me}, \mathrm{Bn}$

$60 \%$ ee

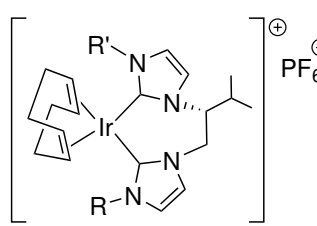

$\mathrm{R}=\mathrm{Me} ; \mathrm{R}^{\prime}=\mathrm{Me}$

$\mathrm{R}=\mathrm{Me} ; \mathrm{R}^{\prime}={ }^{n} \mathrm{Pr}$

$\mathrm{R}=\mathrm{Me} ; \mathrm{R}^{\prime}={ }^{i} \mathrm{Pr}$

$\mathrm{R}=\mathrm{Me} ; \mathrm{R}^{\prime}=\mathrm{CHPh}_{2}$

$\mathrm{R}={ }^{i} \mathrm{Pr} ; \mathrm{R}^{\prime}={ }^{n} \mathrm{Pr}$

$\mathrm{R}=\mathrm{Ph} ; \mathrm{R}^{\prime}={ }^{n} \mathrm{Pr}$

Figure 2. A few examples of previously reported iridium NHC catalysts and their optimal ee's for asymmetric transfer hydrogenation of various ketone substrates.

A rare example of a highly enantioselective noble metal NHC catalyst for ATH of ketones was reported by Yoshida et al. in 2015 [53]. The system incorporated a series of chiral bicyclic NHC ligands featuring a variety of different substituents. Optimal results 
were achieved when employing the catalyst variant shown in Figure 3, which reduces a variety of acetophenone derivatives in as high as $97 \%$ enantiomeric excess. Similar to many of the chiral ligands that have previously been investigated for asymmetric catalysis, preparation of the NHC precursors requires a multistep synthetic pathway in combination with several chromatographic separation techniques.<smiles></smiles>

Figure 3. Highly enantioselective iridium NHC catalyst for ATH of ketones designed by Yoshida.

Given how frequently transition metal catalysts featuring NHC ligands are reported in contemporary literature, the lack of noble metal NHC catalysts displaying practical enantioselectivity for ATH of ketones is rather surprising. Although there are many examples of highly enantioselective direct asymmetric hydrogenation catalysts of this type [38], transfer hydrogenation is typically preferred due to operational simplicity, as it eliminates the need for for a pressured vessel of $\mathrm{H}_{2}$ gas in the experimental setup, and often uses inexpensive, readily available chemicals as the hydrogen donor instead. In this article, we report an iridium NHC catalytic system that gives good to excellent enantioselectivity for a range of aryl ketone substrates. The catalysts designed in this work have all the benefits typically provided by strongly $\sigma$-donating NHC spectator ligands, but incorporate simple, synthetically accessible NHC scaffolds in combination with with "off-the-shelf" chiral $\alpha$-amino acid ligands, rather than costly or synthetically challenging chiral ligands usually employed in asymmetric transformations (Figure 4). This consequently allows for easy fine-tuning and optimization of the catalytic system for asymmetric transfer hydrogenation of ketones.

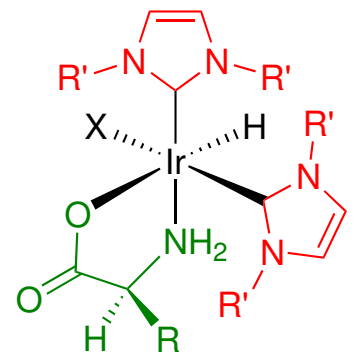

\section{NHC}

Amino acid

Figure 4. Structure and modularity of iridium NHC amino acid complexes reported in this article for asymmetric transfer hydrogenation of ketones, highlighting features that have potential for specific tailoring. These complexes incorporate inexpensive, easily accessible ligands, and conveniently contain a hydride on the metal center prior to initiating the catalysis.

\section{Results and Discussion}

\subsection{Synthesis}

Iridium COD bis-NHC complexes (COD $=1,5$-cyclooctadiene) were found to undergo oxidative addition with a range of $\alpha$-amino acids, generating complexes of the form $\operatorname{Ir}(\mathrm{NHC})_{2}(\mathrm{aa})(\mathrm{H})(\mathrm{X})$, where aa $=$ chelated amino acid and $\mathrm{X}=$ halide (Scheme 2). A Schlenk flask was charged with the desired iridium COD bis-NHC complex, amino acid, and water. 
Upon heating the mixture to $100{ }^{\circ} \mathrm{C}$, both reagents fully dissolved, and the solution was allowed to react for a period of $12 \mathrm{~h}$, over which time the color changed from bright orange to light yellow. Following organic workup, the products were isolated as off-white solids in variable yields (Table 1 ).

$$
\left[\operatorname{Ir}(\mathrm{COD})(\mathrm{NHC})_{2}\right] \mathrm{X}+\alpha \text {-amino acid } \frac{\mathrm{H}_{2} \mathrm{O}, 100^{\circ} \mathrm{C}}{-\mathrm{COD}} \operatorname{Ir}(\mathrm{NHC})_{2}(\mathrm{aa})(\mathrm{H})(\mathrm{X})
$$

Scheme 2. Synthesis of novel iridium NHC amino acid complexes by oxidative addition of $\alpha$-amino acids, where aa $=$ chelated amino acid and $\mathrm{X}=$ halide.

Table 1. Scope and synthetic yields of iridium NHC amino acid complexes featured in this work.

\begin{tabular}{ccc}
\hline NHC & Amino Acid & Yield (\%) \\
\hline & glycine & 53 \\
& L-alanine & 78 \\
& L-valine & 87 \\
IMe $^{\mathrm{a}}$ & L-phenylglycine & 66 \\
& L-azetidine-2-carboxylic acid & 55 \\
& L-proline & 92 \\
& D-proline & 72 \\
\hline $\mathrm{IEt}^{\mathrm{a}}$ & cis-4-fluoro-L-proline & 44 \\
\hline $\mathrm{I}^{i} \mathrm{Pr}^{\mathrm{b}}$ & L-pipecolic acid & 66 \\
\hline
\end{tabular}

${ }^{\mathrm{a}} \mathrm{X}=\mathrm{I}^{-} ;{ }^{\mathrm{b}} \mathrm{X}=\mathrm{Cl}^{-}$.

\subsection{Characterization}

\subsubsection{X-ray Crystallography}

Early in our studies, a yellow single-crystal of $\operatorname{Ir}(\mathrm{IMe})_{2}(\mathrm{Gly})(\mathrm{H})(\mathrm{I})$ suitable for Xray diffraction was collected from an NMR sample in $\mathrm{CDCl}_{3}$, providing insight into the chemical connectivity of these complexes. The solved crystal structure of the glycine complex is shown in Figure 5, and selected bond lengths and angles are provided in Table 2. The complex crystallized in the triclinic space group $P \overline{1}(\# 2)$. The geometry around the iridium center in pseudo-octahedral, with the largest angle (C4-Ir1-O1) having a deviation of $11.52^{\circ}$ from the ideal $90^{\circ}$ due to the bidentate nature of the amino acid ligand. The Ir1-C1 bond length (NHC trans to the iodide) is $1.986 \AA$, while the Ir1-C4 bond length (NHC trans to the chelated nitrogen) is $2.004 \AA$, giving an average Ir-NHC bond distance of $1.995 \AA$. Both Ir-NHC bond lengths in $\operatorname{Ir}(\mathrm{IMe})_{2}(\mathrm{Gly})(\mathrm{H})(\mathrm{I})$ fall within the range of similar complexes that have been published in the literature, with a search of the Cambridge Structural Database (CSD) giving 75 hits for previously reported octahedral Ir III bis-NHC complexes, which feature Ir-NHC bond lengths ranging from 1.910-2.116 $\AA$. 


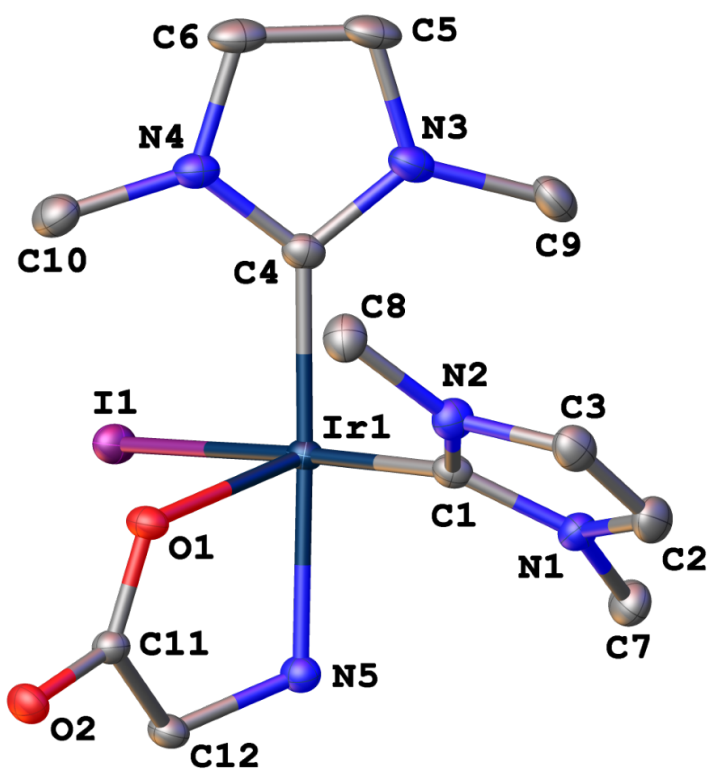

Figure 5. Displacement ellipsoid plot (50\% probability) of $\operatorname{Ir}(\mathrm{IMe})_{2}(\mathrm{Gly})(\mathrm{H})(\mathrm{I})$ (CSD 2062242). The complex crystallized in the triclinic space group $P \overline{1}$. Hydrogen atoms are omitted for clarity.

Table 2. Selected bond lengths and angles from the crystal structure of $\operatorname{Ir}(\mathrm{IMe})_{2}(\mathrm{Gly})(\mathrm{H})(\mathrm{I})$.

\begin{tabular}{cc}
\hline Atoms & Bond Lengths $(\AA)$ \\
\hline Ir1-C1 & 1.986 \\
Ir1-C4 & 2.004 \\
Ir1-O1 & 2.231 \\
Ir1-N5 & 2.157 \\
Ir1-I1 & 2.738 \\
\hline Atoms & Bond Angles ( ${ }^{\circ}$ \\
\hline C1-Ir1-C4 & 89.39 \\
C1-Ir1-O1 & 91.49 \\
C1-Ir1-N5 & 90.53 \\
C4-Ir1-O1 & 101.52 \\
C4-Ir1-I1 & 93.28 \\
O1-Ir1-I1 & 91.60 \\
N5-Ir1-I1 & 86.85 \\
\hline
\end{tabular}

Though hydride ligands in noble metal complexes are often difficult to detect by single-crystal X-ray diffraction, a hydride resonance is observed far upfield in the ${ }^{1} \mathrm{H}$ NMR spectra of $\operatorname{Ir}(\mathrm{IMe})_{2}(\mathrm{Gly})(\mathrm{H})(\mathrm{I})$ at $-24.33 \mathrm{ppm}$ and it is apparent that based on the octahedral geometry of the crystal structure, the hydride is located trans to the chelated oxygen of the amino acid. This aligns the hydride and amine protons in a fashion that should be well-suited for outer-sphere transfer hydrogenation, although this crystal structure is not necessarily representative of the structural orientation in solution. The NHC ligands in $\operatorname{Ir}(\mathrm{IMe})_{2}(\mathrm{Gly})(\mathrm{H})(\mathrm{I})$ appear to be rotated in a particular orientation to minimize steric interactions, with the N1 and N3 substituents of the NHC ligands directed towards the hydride face of the metal. This likely has ramifications in employing these complexes as catalysts for ATH, as longer chain or bulkier N-substituents may obstruct the approach or alignment of an incoming substrate. It should be noted that four unique resonances arising from the NHC methyl groups are observed in the ${ }^{1} \mathrm{H}$ NMR spectra of these complexes, indicating restricted rotation about the $\mathrm{Ir}-\mathrm{NHC}$ bonds.

\subsubsection{Stereochemistry}

Using the crystal structure of the glycine complex as a template for chemical connectivity, it is apparent that upon oxidative addition of the amino acid, an octahedral 
stereogenic metal center is formed. The simplest amino acid glycine, which is achiral, produces two metal enantiomers having absolute configurations of $C$ or $A$ at the iridium center. When homochiral primary amino acids are used, two metal diastereomers of the form $\operatorname{Ir}_{C} C_{S}$ or $\operatorname{Ir}_{A} C_{S}$ are generated, where $S$ represents the configuration at the $\alpha$-carbon of the amino acid. Amino acids containing secondary amines, such as proline, have an additional center of chirality at the nitrogen. This leads to the potential formation of four possible diastereomeric products: $\operatorname{Ir}_{C} C_{S} N_{S}, \operatorname{Ir}_{C} C_{S} N_{R}, \operatorname{Ir}_{A} C_{S} N_{S}$, and $\operatorname{Ir}_{A} C_{S} N_{R}$ (Figure 6).
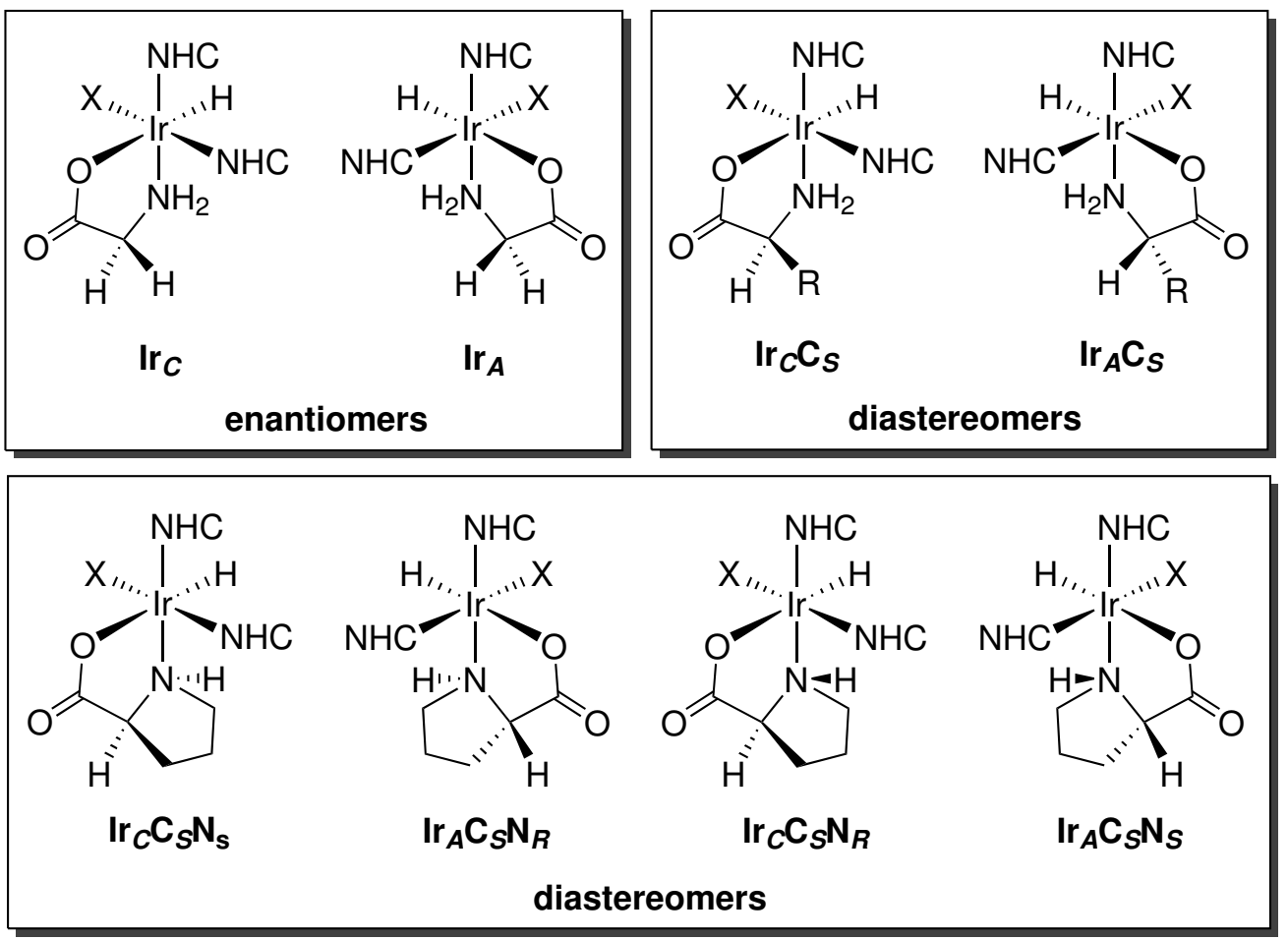

Figure 6. Upon oxidative addition, two metal enantiomers are formed when glycine is used (top-left). Employing a homochiral primary amino acid gives rise to a pair of metal diastereomers (top-right), while incorporation of a secondary amino acid such as L-proline gives rise to four possible metal diastereomers (bottom).

\subsection{3. ${ }^{1} \mathrm{H}$ NMR Spectroscopy}

The hydride resonances in the ${ }^{1} \mathrm{H}$ NMR spectra (DMSO- $d_{6}$ ) of these complexes are observed far upfield beyond $-23 \mathrm{ppm}$. As expected, only one hydride resonance is observed in the spectra of the glycine complex, as the two metal enantiomers are indistinguishable by ${ }^{1} \mathrm{H}$ NMR spectroscopy. Complexes featuring homochiral primary amino acids (Ala, Val, and Phg) display two hydride resonances, confirming the formation of two metal diastereomers (Figure 7). The diastereomeric ratios were determined by integration of these two resonances in order to distinguish between the major and minor isomers. The ${ }^{1} \mathrm{H}$ NMR spectra are significantly more complicated upon the incorporation of secondary amino acids (Aze, Pro, Pip), with numerous hydride resonances observed beyond $-24 \mathrm{ppm}$. This is attributable to the formation of two additional metal diastereomers arising from the extra chiral center on the nitrogen as expected, but also from the presence of other structural isomers. The number and ratios of the hydride resonances in the secondary amino acid complexes were found to change significantly over time in different NMR solvents, suggesting various exchange processes are occurring. 
Gly

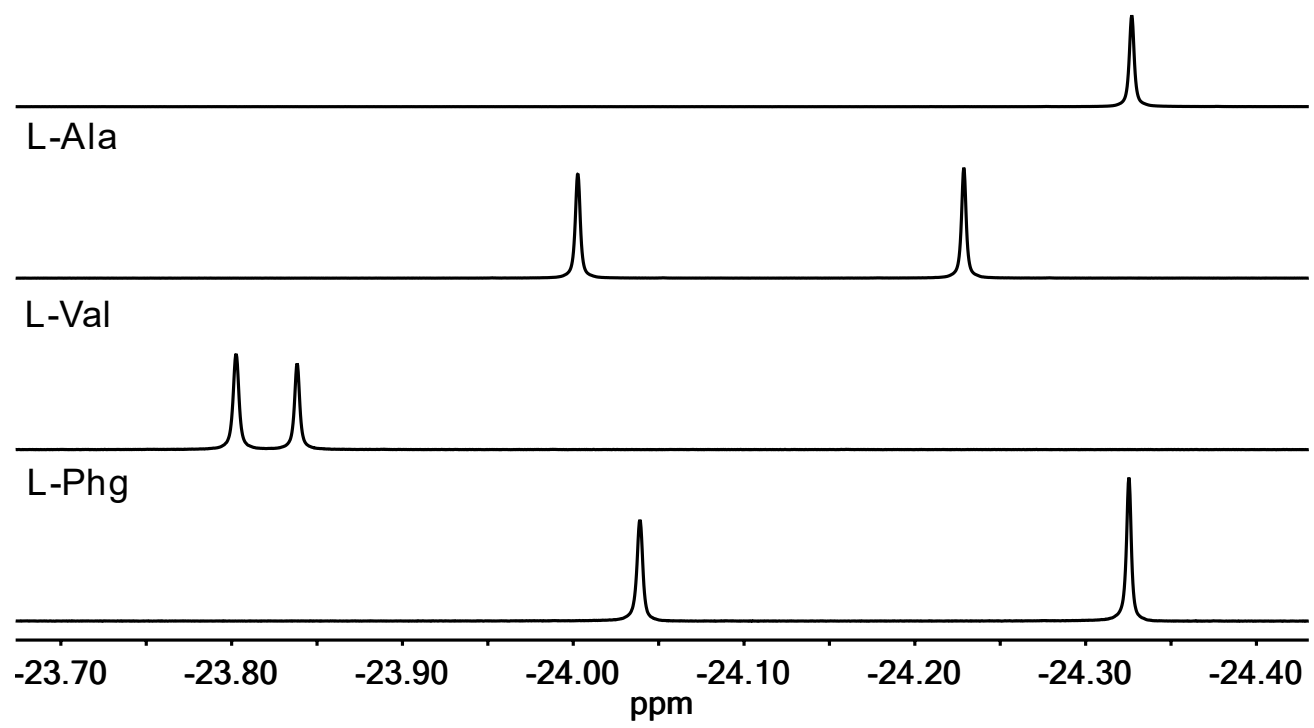

Figure 7. ${ }^{1} \mathrm{H}$ NMR spectra (400 MHz, DMSO- $d_{6}$ ) showing the hydride resonances for complexes of the form $\operatorname{Ir}(\mathrm{IMe})_{2}(\mathrm{aa})(\mathrm{H})(\mathrm{I})$, where aa = glycine, L-alanine, L-valine, and L-phenylglycine.

\subsection{Asymmetric Transfer Hydrogenation of Ketones}

\subsubsection{Initial Catalytic Studies}

Catalytic activity for transfer hydrogenation was initially investigated using the substrate acetophenone. Three catalysts were screened in these preliminary studies, all having the same NHC ligand (IMe), but different amino acids (Gly, L-Ala, L-Pro). Trials were carried out in water employing sodium formate as the hydrogen donor, and in isopropyl alcohol with sodium hydroxide base (Scheme 3). After $24 \mathrm{~h}$, the catalyst was extracted from the reaction mixture, and catalytic activity was assessed via ${ }^{1} \mathrm{H}$ NMR spectroscopy to observe any significant conversion of acetophenone to 1-phenylethanol. Reactions carried out in water displayed only moderate activity, reducing acetophenone in under $60 \%$ conversion after $24 \mathrm{~h}$. Trials in IPA were more promising, particularly the catalyst containing the secondary amino acid L-proline (Table 3).<smiles>CC(=O)c1ccccc1</smiles>

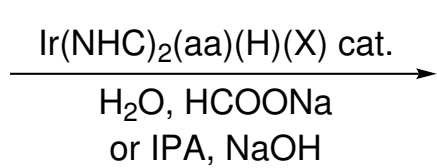<smiles>CC(O)c1ccccc1</smiles>

Scheme 3. Reduction of acetophenone catalyzed by $\operatorname{Ir}(\mathrm{NHC})_{2}(\mathrm{aa})(\mathrm{H})(\mathrm{X})$ complexes.

Table 3. Initial catalytic results for the reduction of acetophenone. All trials were carried out using $2.5 \mathrm{~mol} \%$ of catalyst at $80^{\circ} \mathrm{C}$ over a period of $24 \mathrm{~h}$.

\begin{tabular}{cccc}
\hline Solvent & NHC & Amino Acid & Conv. (\%) \\
\hline \multirow{2}{*}{$\mathrm{H}_{2} \mathrm{O}^{\mathrm{a}}$} & & glycine & 44 \\
& \multirow{2}{*}{$\mathrm{IMe}^{\mathrm{c}}$} & L-alanine & 50 \\
& & L-proline & 59 \\
\hline \multirow{2}{*}{$\mathrm{IPA}^{\mathrm{b}}$} & \multirow{2}{*}{$\mathrm{IMe}^{\mathrm{c}}$} & glycine & 76 \\
& & L-alanine & 86 \\
& & L-proline & 98 \\
\hline
\end{tabular}

a 500 equiv. $\mathrm{HCOONa} ;{ }^{\mathrm{b}} 2$ equiv. $\mathrm{NaOH}$ (equiv. relative to catalyst); ${ }^{\mathrm{c}} \mathrm{X}=\mathrm{I}^{-} ;{ }^{\mathrm{d}}$ Conversion was quantified via

${ }^{1} \mathrm{H}$ NMR spectroscopy using 1,3,5-trimethoxybenzene as an internal standard.

Since these catalysts were active for transfer hydrogenation in the NMR studies, catalytic trials in IPA were conducted again, this time screening for asymmetric reduction. A wider scope of catalysts were employed, all having the same NHC ligand (IMe), but a 
variety of primary and secondary amino acids. Conversion and enantiomeric excess were quantified after $24 \mathrm{~h}$ by chiral gas chromatography. As expected, the catalyst containing the achiral amino acid glycine generated a racemic mixture of the 1-phenylethanol product. While catalysts featuring L-Ala, L-Val, L-Phg, L-Aze, and L-Pip all displayed poor enantioselectivity, the L-proline variant reduced acetophenone in $68 \%$ ee of the $R$-enantiomer. Incorporation of D-proline generated the opposite configuration of the the alcohol product $(S)$ in the same enantiomeric excess (Table 4).

Table 4. Initial catalytic results for the ATH of acetophenone. All trials were carried out using $2.5 \mathrm{~mol} \%$ of catalyst and 2 equiv. of $\mathrm{NaOH}$ in IPA at $80^{\circ} \mathrm{C}$ over a period of $24 \mathrm{~h}$.

\begin{tabular}{|c|c|c|c|c|}
\hline NHC & Amino Acid & Conv. $(\%)^{b}$ & ee $(\%)^{b}$ & Conf. \\
\hline \multirow{8}{*}{$\mathrm{IMe}^{\mathrm{a}}$} & glycine & 75 & 0 & - \\
\hline & L-alanine & 81 & 3 & $R$ \\
\hline & L-valine & 74 & 5 & $R$ \\
\hline & L-phenylglycine & 77 & 6 & $R$ \\
\hline & L-azetidine-2-carboxylic acid & 83 & 17 & $R$ \\
\hline & L-proline & 98 & 68 & $R$ \\
\hline & D-proline & 95 & 68 & $S$ \\
\hline & L-pipecolic acid & 82 & 4 & $S$ \\
\hline
\end{tabular}

${ }^{\mathrm{a}} \mathrm{X}=\mathrm{I}^{-} ;{ }^{\mathrm{b}}$ Conversion and enantiomeric excess were quantified via chiral GC-FID using 1,3,5-trimethoxybenzene as an internal standard.

In order to gain insight into the active catalytic species, room temperature ${ }^{1} \mathrm{H}$ NMR spectra (IPA, DMSO- $d_{6}$ insert) of $\operatorname{Ir}(\mathrm{IMe})_{2}$ (L-Pro)(H)(I) were acquired before and after the addition of base (Figure 8). As mentioned previously, a variety of hydride resonances were observed in the spectrum of just the initial complex. Upon adding 2 equivalents of $\mathrm{NaOH}$, there was a notable change in the hydride region. One major resonance emerged at $-24.60 \mathrm{ppm}$, accompanied by three minor resonances at $-26.84,-27.07$ and $-27.33 \mathrm{ppm}$. This may indicate the presence of four potentially active catalytic species as suggested earlier, presumably generated by dissociation of the iodide anion. The downfield portion of the spectrum still featured numerous overlapping resonances, and the precise structures of these species could not be elucidated from this experiment.

\section{Complex}
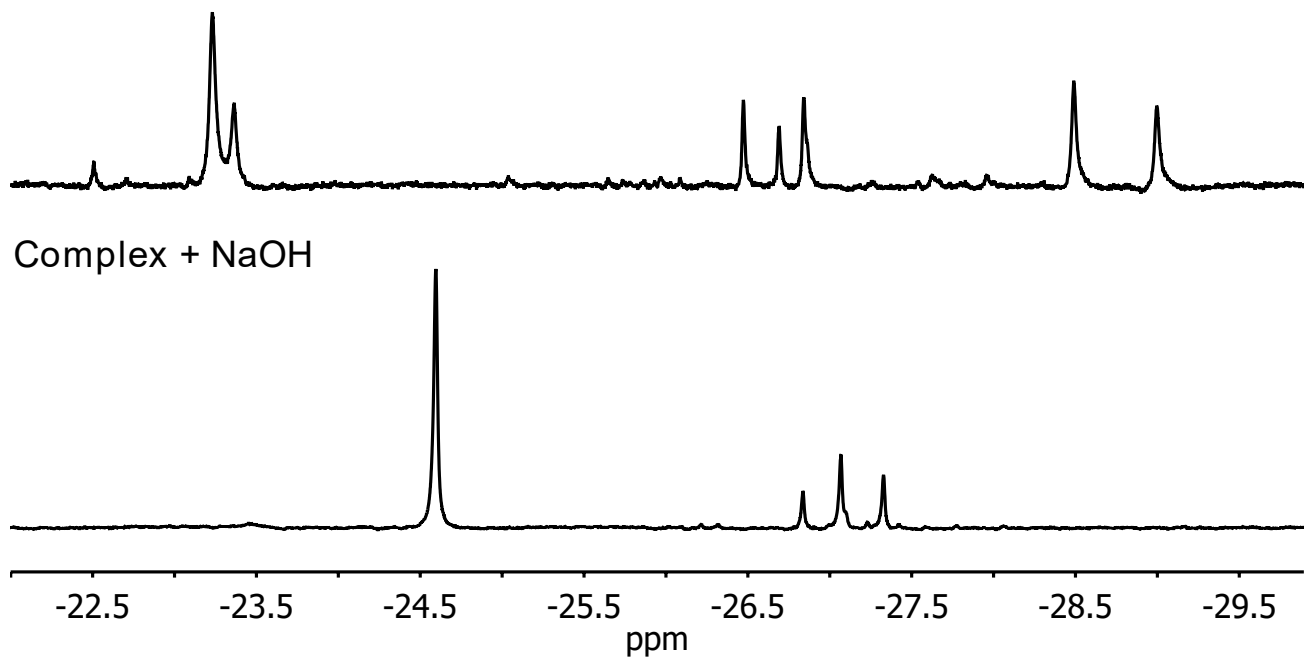

Figure 8. ${ }^{1} \mathrm{H}$ NMR spectra (400 MHz, IPA, DMSO- $d_{6}$ insert) showing the hydride resonances of $\operatorname{Ir}(\mathrm{IMe})_{2}(\mathrm{~L}-\mathrm{Pro})(\mathrm{H})(\mathrm{I})$ before (top) and after (bottom) the addition of $\mathrm{NaOH}$.

\subsubsection{Optimization: Temperature}

Catalytic trials were carried out at temperatures of $25,40,60$, and $80^{\circ} \mathrm{C}$ using $2.5 \mathrm{~mol} \%$ of $\operatorname{Ir}(\mathrm{IMe})_{2}(\mathrm{~L}-\mathrm{Pro})(\mathrm{H})(\mathrm{I})$ and 2 equivalents of $\mathrm{NaOH}$ in isopropyl alcohol. All reactions 
were monitored by chiral GC at specific time increments over a period of $48 \mathrm{~h}$ in order to quantify conversion (Figure 9) and enantiomeric excess (Figure 10) over the course of the catalysis. No significant induction period was observed for any of the trials, with the catalysis beginning immediately upon addition of base. This was attributed to the presence of a hydride on the complex prior to catalysis initiation. As expected, catalytic activity is higher at elevated temperatures, giving initial turnover frequencies as high as $1029 \mathrm{~h}^{-1}$ at $80^{\circ} \mathrm{C}$, compared to $57 \mathrm{~h}^{-1}$ at $25^{\circ} \mathrm{C}$. Conversion began to level off over time in all trials, implying the active catalyst could be degrading.

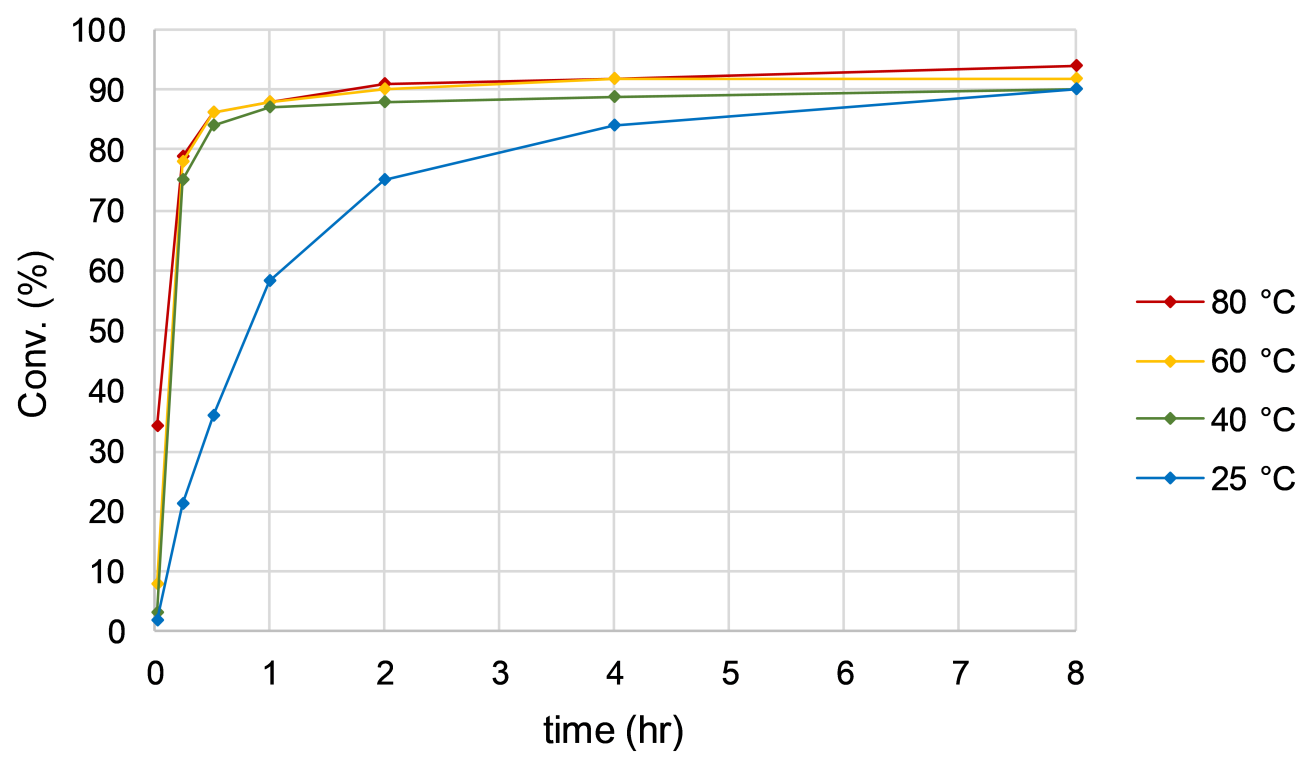

Figure 9. Conversion of acetophenone over time at various temperatures. All conversions appeared to level off after a period of $8 \mathrm{~h}$.

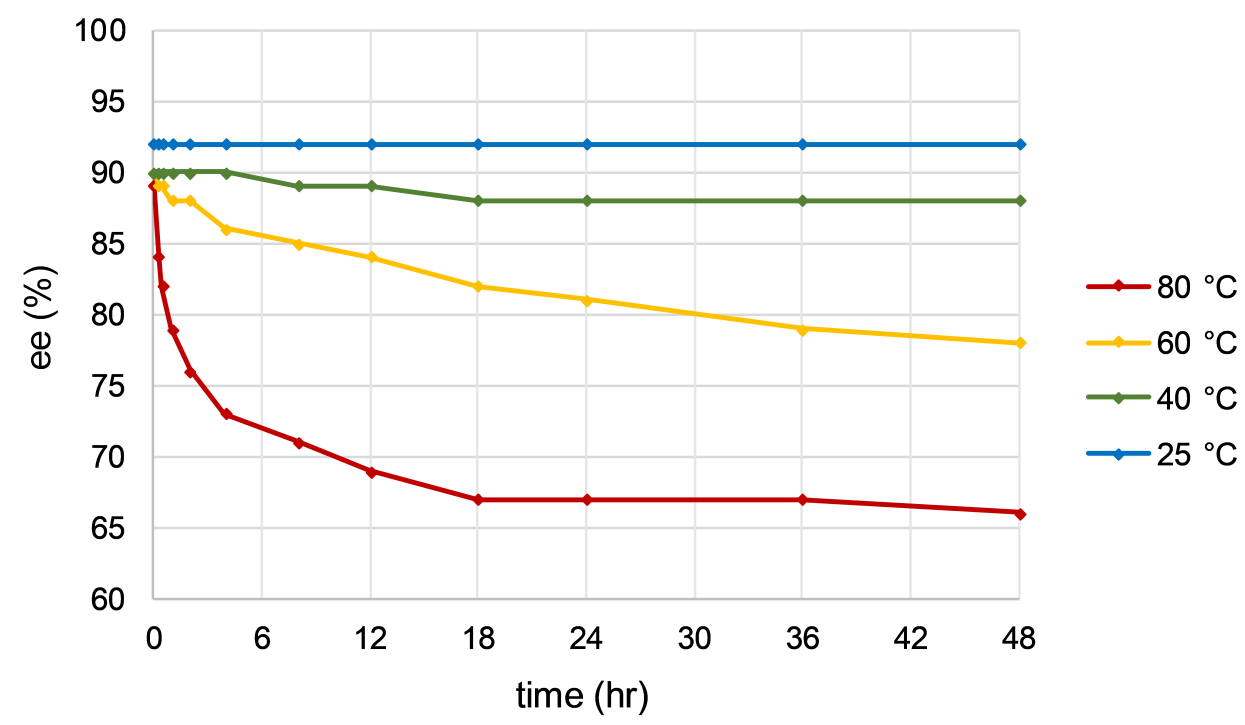

Figure 10. Enantiomeric excess of 1-phenylethanol over time at various temperatures. Enantioselectivity degraded over time at temperatures above $25^{\circ} \mathrm{C}$.

Optimal enantioselectivity was achieved when carrying out the catalysis at $25^{\circ} \mathrm{C}$, with generation of $R$-1-phenylethanol in $92 \%$ ee, a notable increase from the $68 \%$ ee observed in the initial ATH studies. Enantiomeric excess of the product gradually decreased over the course of the reaction at higher temperatures, most notably at $80^{\circ} \mathrm{C}$, where the ee fell from $89 \%$ to $66 \%$ after $48 \mathrm{~h}$. The phenomenon is often attributed to a higher energy metal 
diastereomeric transition state becoming relatively more favorable at elevated temperatures, though it is possible higher temperatures facilitate product racemization by an achiral metal species generated via catalyst degradation.

\subsubsection{Optimization: Base}

A range of different bases was screened using $2.5 \mathrm{~mol} \%$ of the $\operatorname{Ir}(\mathrm{IMe})_{2}(\mathrm{~L}-\mathrm{Pro})(\mathrm{H})(\mathrm{I})$ catalyst in IPA at $25{ }^{\circ} \mathrm{C}$ over a period of $24 \mathrm{~h}$. Practically no substrate conversion was observed when employing the weak bases $\mathrm{Na}_{2} \mathrm{CO}_{3}, \mathrm{NaHCO}_{3}$, or $\mathrm{HCOONa}$. This is likely attributable to slower regeneration of the active catalyst, as weaker bases are typically less efficient in promoting the oxidation of IPA to acetone by the metal center via $\beta$-hydride elimination. Using $\mathrm{KOH}$ in lieu of $\mathrm{NaOH}$ gave no notable enhancement in activity. Trials were then carried out using different amounts of $\mathrm{NaOH}$ to probe any effects on conversion or enantioselectivity (Figure 11). No notable substrate conversion occurred in the absence of base, while 1 equivalent of $\mathrm{NaOH}$ gave just over $60 \%$ conversion. Conversion steadily declined when employing any amount over 2 equivalents of $\mathrm{NaOH}$, indicating excess hydroxide may poison the catalyst. Varying the amount of base did not significantly affect enantioselectivity.

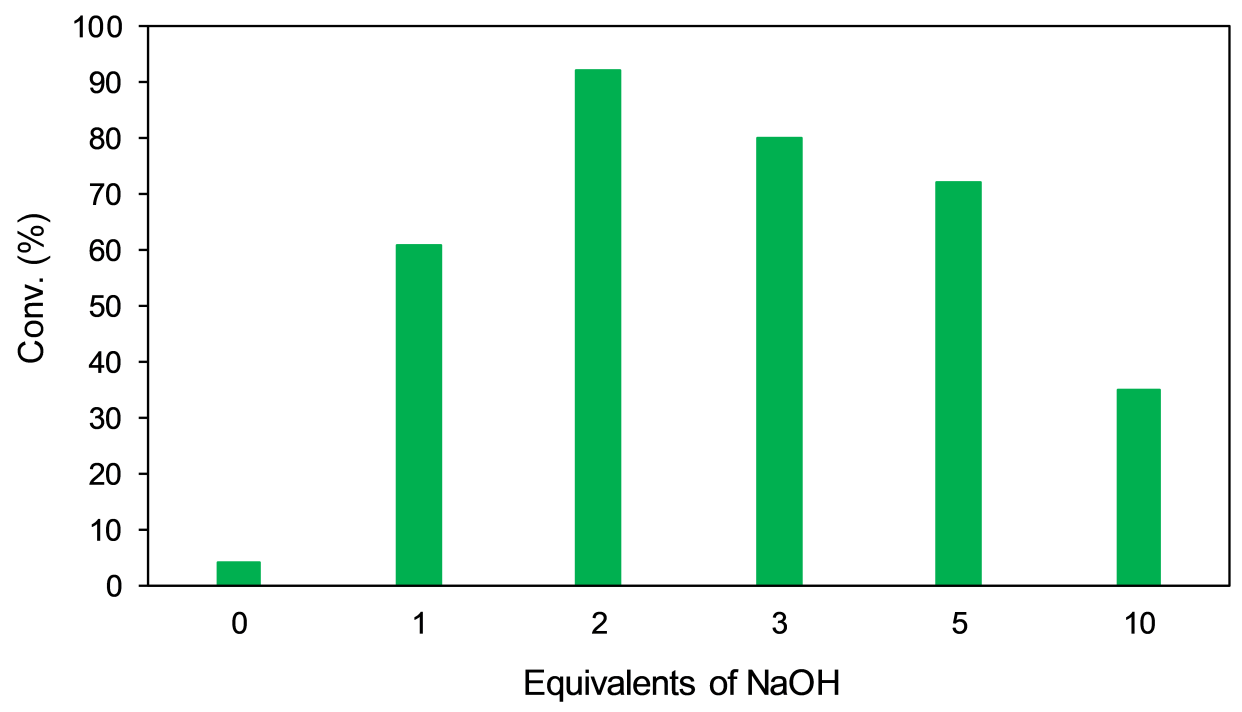

Figure 11. Effect of varying the amount of $\mathrm{NaOH}$ on the conversion of acetophenone. Little to no conversion of acetophenone was observed when employing weaker bases.

\subsubsection{Optimization: Catalyst Loading}

Trials were carried out at different catalyst loadings of $\operatorname{Ir}(\mathrm{IMe})_{2}$ (L-Pro)(H)(I) with 2 equivalents of $\mathrm{NaOH}$ in IPA at $25^{\circ} \mathrm{C}$ over a period of $24 \mathrm{~h}$ (Figure 12). As expected, no conversion was observed when the catalyst was omitted from the reaction. Conversion was found to steadily increase with catalyst loading in the other trials, although there was not a notable enhancement in activity when going from 2.5 to $5 \mathrm{~mol} \%$ of catalyst. Enantioselectivity remained consistent regardless of the catalyst loading, with all five trials generating $R$-1-phenylethanol in $92 \%$ ee. 


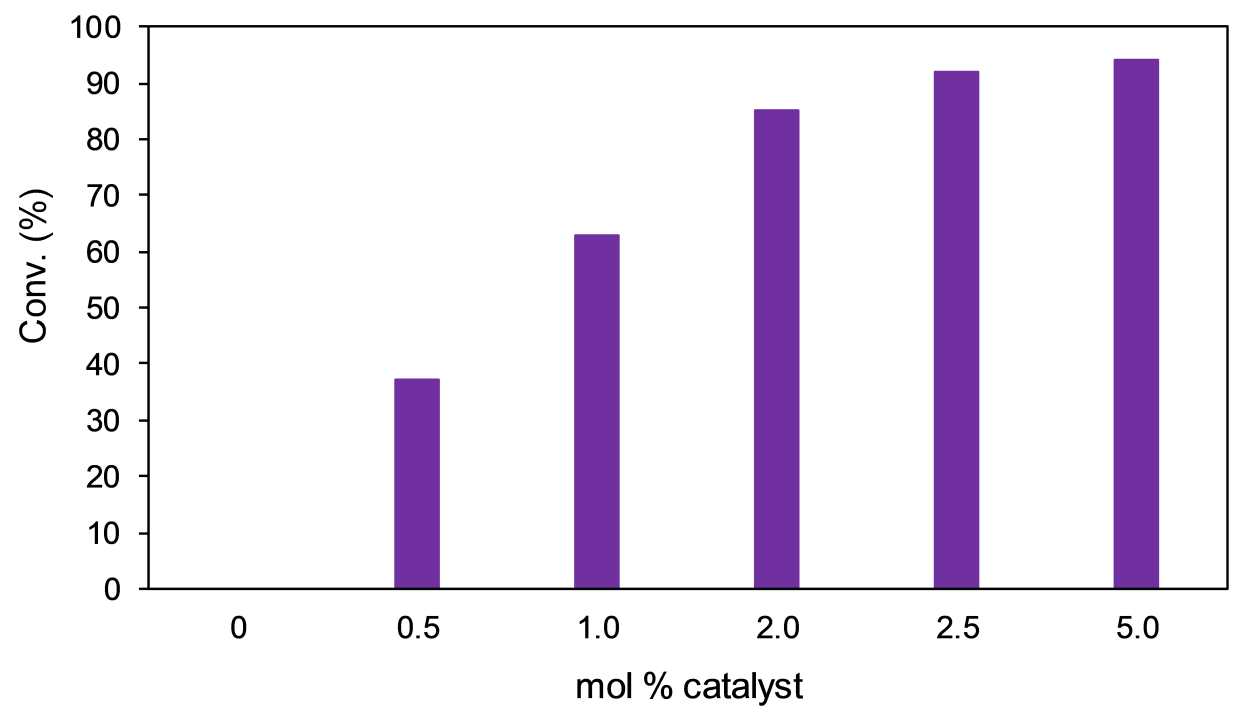

Figure 12. Effect of varying the catalyst loading on the conversion of acetophenone.

\subsubsection{Optimized Results: Catalyst Scope}

Following optimization, all iridium NHC amino acid complexes synthesized in this work were screened for ATH of acetophenone using $2.5 \mathrm{~mol} \%$ of catalyst and 2 equivalents of $\mathrm{NaOH}$ in IPA at $25^{\circ} \mathrm{C}$ (Table 5). Although the majority of catalysts gave lower conversions at $25^{\circ} \mathrm{C}$ than seen in the initial trials at $80^{\circ} \mathrm{C}$, enantioselectivity was improved in all cases. Catalysts featuring the amino acids Aze, Pro, and Pip generated 1-phenylethanol in higher enantiomeric excess than those containing primary amino acids, indicating secondary amino acids are essential to achieve reasonable enantioselectivity in this system. While the L-Aze catalyst gave a notable increase in ee at room temperature, the proline-based catalysts are clearly superior to all other in terms of activity and enantioselectivity. Incorporation of IEt or I Pr NHC ligands in lieu of IMe achieved nearly complete conversion of acetophenone, but at the expense of enantioselectivity. Enantiomeric excess notably decreased as the steric bulk of the NHC N-substituents increased. The high conversions indicate the face of the metal is not completely blocked, but as suggested earlier when evaluating the X-ray crystal structure of the glycine complex, larger N-substituents appear to obstruct the alignment of the incoming substrate, eroding enantioselectivity.

Table 5. Catalyst scope for ATH of acetophenone using the optimized catalytic conditions. Error values are representative of the absolute mean residual from three independent trials.

\begin{tabular}{ccccc}
\hline NHC & Amino Acid & Conv. (\%) & ee (\%) & Conf. \\
\hline & glycine & $46 \pm 2$ & 0 & - \\
& L-alanine & $52 \pm 1$ & $9 \pm 1$ & $R$ \\
L-valine & $45 \pm 3$ & $6 \pm 1$ & $R$ \\
$\mathrm{IMe}^{\mathrm{a}}$ & L-phenylglycine & $49 \pm 2$ & $8 \pm 1$ & $R$ \\
& L-azetidine-2-carboxylic acid & $56 \pm 1$ & $67 \pm 2$ & $R$ \\
& L-proline & $91 \pm 1$ & $92 \pm 1$ & $R$ \\
& D-proline & $92 \pm 2$ & $92 \pm 1$ & $S$ \\
& cis-4-fluoro-L-proline & $44 \pm 2$ & $89 \pm 2$ & $R$ \\
\hline $\mathrm{IEt}^{\mathrm{a}}$ & L-pipecolic acid & $55 \pm 3$ & $17 \pm 1$ & $S$ \\
\hline $\mathrm{I}^{i} \operatorname{Pr}^{\mathrm{b}}$ & L-proline & $98 \pm 1$ & $55 \pm 2$ & $R$ \\
\hline
\end{tabular}

${ }^{\mathrm{a}} \mathrm{X}=\mathrm{I}^{-} ;{ }^{\mathrm{b}} \mathrm{X}=\mathrm{Cl}^{-}$.

The majority of these catalysts generated the $R$-enantiomer of 1-phenylethanol in excess. Changing the configuration of a particular amino acid led to an excess of the opposite enantiomer, as demonstrated from the trials employing L- and D-proline. Of all the catalysts screened that incorporated L-amino acids, only the L-Pip variant gave an 
excess of the $S$-enantiomer. This phenomenon was also observed for noble metal amino acid ATH catalysts of the form $\left(\mathrm{Cp}^{* \mathrm{R}}\right) \operatorname{Ir}(\mathrm{aa}) \mathrm{Cl}$ previously reported by the Merola group, with those studies finding that the configurations of the alcohol products directly correlated to the crystallographically observed configurations of the chelated amino acid nitrogens [34]. The crystal structure of $\left(\mathrm{Cp}^{*}\right) \operatorname{Ir}(\mathrm{L}-\mathrm{Pip}) \mathrm{Cl}$ had the opposite configuration at the nitrogen $(R)$ than those containing other secondary L-amino acids (S); thus, the opposite product enantiomer was generated when using the L-Pip catalyst. This could justify why the same trend was observed for the iridium NHC amino acid catalysts as well. Unfortunately, suitable single-crystals of the NHC complexes featuring chiral amino acids could not be grown to confirm the absolute configurations, which may be related to the presence of numerous other isomers, as seen in solution.

\subsubsection{Optimized Results: Substrate Scope}

The $\operatorname{Ir}(\mathrm{IMe})_{2}$ (L-Pro)(H)(I) catalyst was employed in an expanded substrate scope featuring a variety of acetophenone derivatives. All trials were carried out under the optimized catalytic conditions using $2.5 \mathrm{~mol} \%$ of catalyst and 2 equivalents of $\mathrm{NaOH}$ in IPA at $25^{\circ} \mathrm{C}$. Conversion and enantiomeric excess were quantified by chiral GC, and the results are summarized below in Figure 13. The majority of aryl ketone substrates were reduced in good conversions and enantiomeric excess. The highest ee's in the study were observed for acetophenone and propiophenone, giving $92 \%$ and $95 \%$ ee, respectively. Conversion and enantioselectivity were lowered upon screening branched acetophenone derivatives, which may be attributable to unfavorable steric interactions between the isopropyl or tert-butyl groups on the respective substrates and the N-substituents on the NHC ligands. Enantiomeric excess was only marginally lower for acetophenone derivatives featuring $\mathrm{CH}_{3}, \mathrm{~F}, \mathrm{CF}_{3}$, or $\mathrm{Cl}$ substituents on the phenyl ring.<smiles>CC(=O)c1ccccc1</smiles>

acetophenone

$91 \pm 1 \%$ Conv. $92 \pm 1 \%$ ee $(R)$<smiles>CC(C)(C)C(=O)c1ccccc1</smiles>

2,2,2,-trimethylacetophenone

$17 \pm 2 \%$ Conv $21 \pm 2 \%$ ee $(S)$<smiles>CC(=O)c1ccc(F)cc1</smiles>
4'-fluoroacetophenone

$89 \pm 2 \%$ Conv. $86 \pm 2 \%$ ee $(R)$<smiles>CCC(=O)c1ccccc1</smiles>
propiophenone $73 \pm 2 \%$ Conv. $95 \pm 3 \%$ ee $(R)$<smiles>O=C(c1ccccc1)C1CCCCC1</smiles>
cyclohexyl phenyl ketone $31 \pm 2 \%$ Conv. $66 \pm 3 \%$ ee $(S)$<smiles>CC(=O)c1ccc(C(F)(F)F)cc1</smiles>

4'-(trifluoromethyl)acetophenone

$99 \pm 1 \%$ Conv. $87 \pm 1 \%$ ee $(R)$<smiles>CC(C)C(=O)c1ccccc1</smiles>

isobutyrophenone

$23 \pm 2 \%$ Conv. $81 \pm 2 \%$ ee $(R)$<smiles>CC(=O)c1ccc(C)cc1</smiles>

4'-methylacetophenone

$79 \pm 0 \%$ Conv $88 \pm 2 \%$ ee $(R)$<smiles>CCOC(=O)OCCCCOC(=O)OCC</smiles>

$95 \pm 1 \%$ Conv. $87 \pm 1 \%$ ee $(R)$

Figure 13. Substrate scope for ATH of ketones catalyzed by $\operatorname{Ir}(\mathrm{IMe})_{2}(\mathrm{~L}-\mathrm{Pro})(\mathrm{H})(\mathrm{I})$. All reactions were carried out using the optimized catalytic conditions. 


\subsubsection{Proposed Catalytic Mechanism}

While detailed experimental and computational mechanistic studies are ongoing, it is likely that transfer hydrogenation in this system proceeds through an outer-sphere mechanism in a similar fashion to Noyori's metal-ligand bifunctional ruthenium diamine ATH catalyst (Scheme 4). Upon addition of base, the active catalytic species is generated by dissociation of the iodide ligand (A). Simultaneous transfer of the proton and hydride from the catalyst to the substrate occurs via a cyclic six-membered transition state $(\mathbf{B})$. Although the active catalyst can then potentially be regenerated by hydrogen transfer through another cyclic six-membered transition state between IPA and the coordinatively unsaturated species (C), the requirement of a strong base to achieve any substrate conversion in this system (as seen in the base optimization studies) suggests the active catalyst is regenerated by coordination of $J(D)$ and subsequent $\beta$-hydride elimination of acetone.

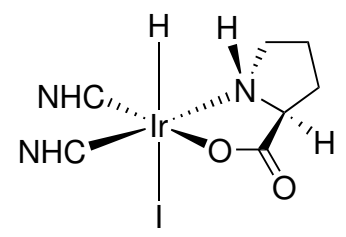

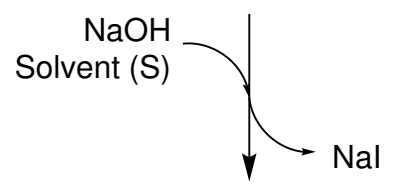
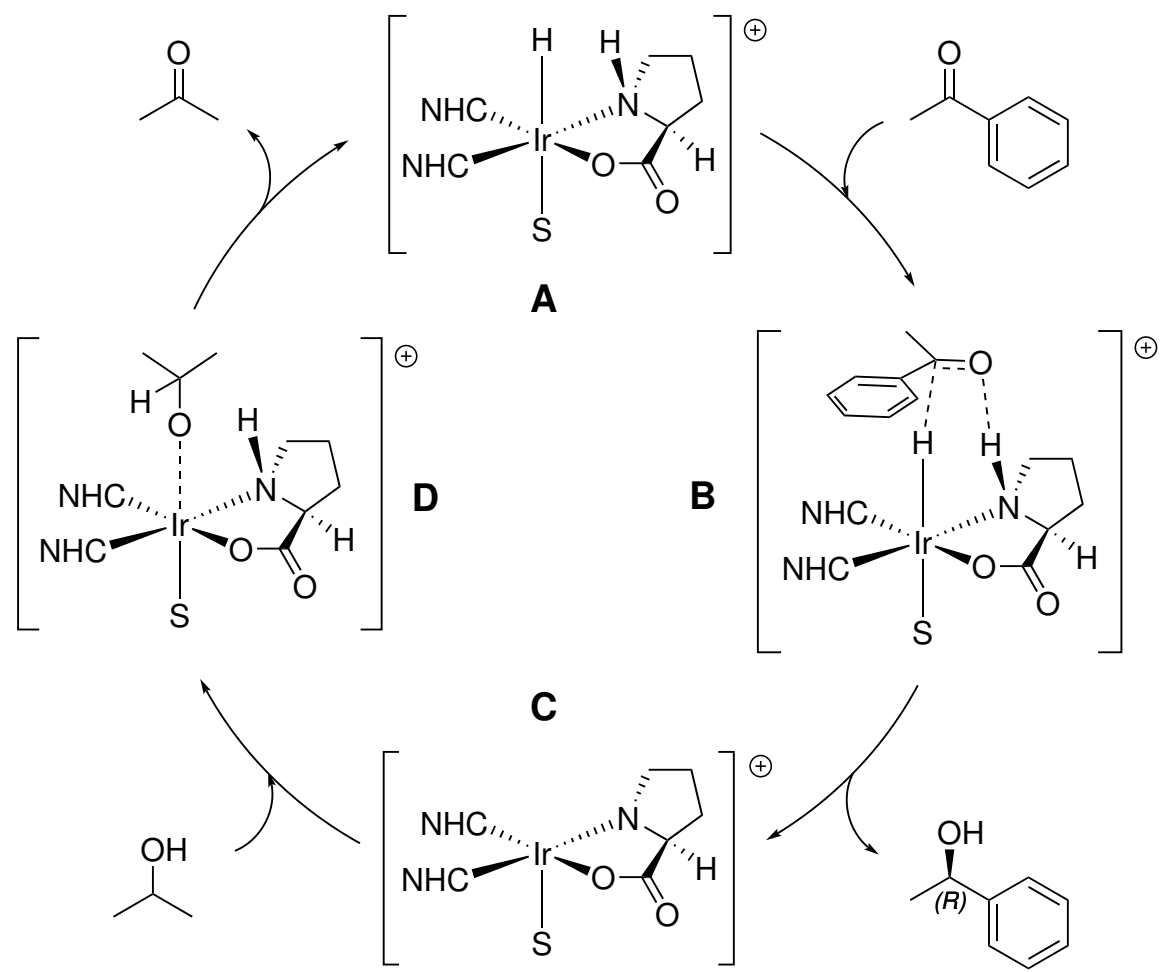

Scheme 4. Proposed catalytic cycle for ATH of aryl ketones in this system, where $\mathrm{S}$ is representative of the solvent (IPA). Steps: A. solvent complexed cationic resting state of catalyst; B. positioning of substrate with hydride attacking the carbonyl carbon and $\mathrm{N}-\mathrm{H}$ bonding to carbonyl oxygen; C. elimination of reduced product; D. coordination of isopropanol followed by reductive elimination to regenerate metal hydride (A). Metal-ligand bifunctional catalysts of this type typically operate through an outer-sphere mechanism, where the substrate does not directly bind to the metal center. 
The small decrease in enantiomeric excess observed when screening electron-withdrawing acetophenone derivatives suggests that if $\mathrm{CH}_{3} / \pi$ interactions are occurring between the aryl group of the substrate and a methyl group on one of the NHC ligands, they are likely not significant. Therefore, it seems most probable that steric inhibition between the alkyl groups of the substrate and NHC N-substituents dominate the enantiodetermining step, as highlighted by the diminished conversions and ee's obtained for branched acetophenone derivatives. This is also supported by the catalytic trials featuring bulkier NHC N-substituents (IEt, I ${ }^{i} \mathrm{Pr}$ ), which still favorably generated the same enantiomer of 1-phenylethanol as the IMe-based catalyst, but in notably lower enantiomeric excess.

\section{Materials and Methods}

Reagent grade solvents and all materials for synthesis, purification, characterization, and catalysis were purchased from commercial sources and used as received unless otherwise stated. Iridium(III) chloride hydrate was purchased from Pressure Chemical (Pittsburgh, PA, USA). 1,3-Diisopropylimidazolium chloride, L-phenylglycine, acetophenone, 4'-chloroacetophenone, and 4'-methylacetophenone were purchased from Sigma Aldrich (St. Louis, MO, USA). L-Alanine, L-pipecolic acid, D-proline, L-proline, L-valine, cyclohexyl phenyl ketone, 4'-fluoroacetophenone, isobutyrophenone, propiophenone, $4^{\prime}$ (trifluoromethyl)acetophenone, and 2,2,2-trimethylacetophenone were purchased from Alfa Aesar (Ward Hill, MA, USA). L-Azetidine-2-carboxylic acid and cis-4-fluoro-L-proline were purchased from Indofine Chemical (Hillsborough, NJ, USA). Glycine was purchased Qiagen Sciences (Germanstown, MD 20874, USA). Deuterated solvents for NMR spectroscopy were obtained from Cambridge Isotope Laboratories (Andover, MA, USA).

${ }^{1} \mathrm{H}$ NMR, ${ }^{13} \mathrm{C}$ NMR, and ${ }^{19} \mathrm{~F}$ NMR spectra were collected on an Agilent U4-DD2 or Agilent MR4 $400 \mathrm{MHz}$ spectrometer. ${ }^{13} \mathrm{C}$ NMR were correspondingly recorded at $101 \mathrm{MHz}$ and ${ }^{19} \mathrm{~F}$ NMR at $376 \mathrm{MHz}$. High-resolution mass spectra were collected on an Agilent 6220 Accurate Mass TOF LC-MS. X-ray crystallographic data were collected at $100 \mathrm{~K}$ on a Rigaku Oxford Diffraction Synergy diffractometer operating with Mo K $\alpha$ radiation. Crystals were coated in Paratone oil and mounted on a fiber. Data collection and data reduction were performed using Agilent's CrysAlisPro software [54]. Structure solution was performed using SHELXT [55] and refined using SHELXL [56] via Olex2. The final refinement model involved anisotropic displacement parameters for non-hydrogen atoms and a riding model for all hydrogen atoms. Olex2 was used for molecular graphics generation [57]. Searches of the Cambridge Structural Database (CSD) [58] were carried out using the program Conquest [59], and the results were analyzed with the statistical functions of the program Mercury [60,61]. GC chromatograms were acquired on a Hewlett Packard 5890 equipped with a flame-ionization detector and CP-ChiraSil-Dex CB $25 \mathrm{~m} \times 0.25 \mathrm{~mm}$ column for determination of conversion and enantiomeric excess (inlet temp $=240{ }^{\circ} \mathrm{C}$, detector temp $=$ $250{ }^{\circ} \mathrm{C}$ ). Column temperatures are provided with the respective GC chromatograms in the Supplemental Information.

\subsection{Synthesis of Imidazolium Salts and Iridium Complex Precursors}

The NHC ligand synthetic precursors 1,3-dimethylimidazolium iodide [62] and 1,3diethylimidazolium iodide [63], as well as the iridium complex synthetic precursors $\left[\operatorname{Ir}(\mathrm{COD}) \mathrm{Cl}_{2}[64],\left[\operatorname{Ir}(\mathrm{COD})(\mathrm{IMe})_{2}\right] \mathrm{I}[65]\right.$, and $\left[\operatorname{Ir}(\mathrm{COD})(\mathrm{IEt})_{2}\right] \mathrm{I}$ [65] were all synthesized and characterized as reported previously.

\subsection{General Procedure for the Synthesis of $\operatorname{Ir}(\mathrm{NHC})_{2}(a a)(\mathrm{H})(\mathrm{X})$ Complexes}

A Schlenk flask was charged with the desired iridium COD bis-NHC complex, amino acid, and $15 \mathrm{~mL}$ of water. Upon heating the mixture to $100^{\circ} \mathrm{C}$, both reagents fully dissolved, and solution was allowed to react for period of $12 \mathrm{~h}$, over which time the color changed from bright orange to light yellow. The water was removed by rotary evaporation, and the crude product was extracted into dichloromethane. After drying with magnesium sulfate, the mixture was filtered through Celite, and the dichloromethane was removed by 
rotary evaporation. Following trituration with diethyl ether, the products were isolated on a fritted glass filter as off-white solids, and dried overnight under vacuum.

\subsubsection{Synthesis of $\operatorname{Ir}(\mathrm{IMe})_{2}(\mathrm{Gly})(\mathrm{H})(\mathrm{I})$}

Following the general procedure: $\left[\operatorname{Ir}(\mathrm{COD})(\mathrm{IMe})_{2}\right] \mathrm{I}(0.2000 \mathrm{~g}, 0.3228 \mathrm{mmol})$ and glycine $(0.0500 \mathrm{~g}, 0.6666 \mathrm{mmol})$ were reacted in water to give $\mathrm{Ir}(\mathrm{IMe})_{2}(\mathrm{Gly})(\mathrm{H})(\mathrm{I})(0.0999 \mathrm{~g}, 53 \%)$. ${ }^{1}$ H NMR (400 MHz, DMSO- $\left.d_{6}, \delta\right): 7.45(\mathrm{~d}, J=2.0 \mathrm{~Hz}, 1 \mathrm{H}, \mathrm{NHC}$ backbone), 7.33 (d, $J=$ $2.0 \mathrm{~Hz}, 1 \mathrm{H}, \mathrm{NHC}$ backbone), $7.31(\mathrm{~d}, J=2.0 \mathrm{~Hz}, 1 \mathrm{H}, \mathrm{NHC}$ backbone), 7.27 (d, $J=1.9 \mathrm{~Hz}$, 1H, NHC backbone), $5.21(\mathrm{~m}, 1 \mathrm{H}, \mathrm{NH}), 4.94(\mathrm{~m}, 1 \mathrm{H}, \mathrm{NH}), 4.06$ (s, 3H, NHC CH $), 3.80$ (s, $3 \mathrm{H}, \mathrm{NHC} \mathrm{CH})_{3}, 3.33-3.25\left(\mathrm{~m}, 1 \mathrm{H}, \alpha \mathrm{CH}_{2}\right), 3.18(\mathrm{~s}, 3 \mathrm{H}, \mathrm{NHC} \mathrm{CH})_{3}, 3.17-3.10\left(\mathrm{~m}, 1 \mathrm{H}, \alpha \mathrm{CH}_{2}\right)$, 2.89 (s, 3H, NHC CH 3$),-24.33$ (s, 1H, hydride). ${ }^{13} \mathrm{C}$ NMR (101 MHz, DMSO- $\left.d_{6}, \delta\right): 178.8$ $(\mathrm{C}(\mathrm{O})), 149.4$ ( $\left.\mathrm{C}_{\text {carbene }}\right), 143.5$ ( $\left.\mathrm{C}_{\text {carbene }}\right), 123.5$ (NHC backbone), 123.2 (NHC backbone), 122.8 (NHC backbone), 122.7 (NHC backbone), $47.0(\alpha \mathrm{C}), 38.3\left(\mathrm{NHC} \mathrm{CH}_{3}\right), 38.2(\mathrm{NHC}$ $\left.\mathrm{CH}_{3}\right), 36.8\left(\mathrm{NHC} \mathrm{CH}_{3}\right), 35.0\left(\mathrm{NHC} \mathrm{CH}_{3}\right)$. HRMS/ESI+ $(\mathrm{m} / z)$ : Calc. for $\mathrm{C}_{12} \mathrm{H}_{21} \mathrm{O}_{2}\left[{ }^{193} \mathrm{Ir}\right] \mathrm{N}_{5}$ : 460.1319; Found: 460.1304.

\subsubsection{Synthesis of $\operatorname{Ir}(\mathrm{IMe})_{2}$ (L-Ala)(H)(I)}

Following the general procedure: $\left[\operatorname{Ir}(\mathrm{COD})(\mathrm{IMe})_{2}\right] \mathrm{I}(0.2000 \mathrm{~g}, 0.3228 \mathrm{mmol})$ and Lalanine $(0.0575 \mathrm{~g}, 0.6456 \mathrm{mmol})$ were reacted in water to give $\mathrm{Ir}(\mathrm{IMe})_{2}(\mathrm{~L}-\mathrm{Ala})(\mathrm{H})(\mathrm{I})(0.1503$ $\mathrm{g}, 78 \%)$. Analysis for major isomer (51\%): ${ }^{1} \mathbf{H}$ NMR (400 MHz, DMSO- $\left.d_{6}, \delta\right): 7.46(\mathrm{~d}, J=1.9 \mathrm{~Hz}$, 1H, NHC backbone), 7.42 (d, $J=1.9 \mathrm{~Hz}, 1 \mathrm{H}, \mathrm{NHC}$ backbone), 7.32 (d, J = 1.9 Hz, 1H, NHC backbone), $7.29(\mathrm{~d}, J=2.0 \mathrm{~Hz}, 1 \mathrm{H}, \mathrm{NHC}$ backbone), 5.07 (dd, $J=12.5,6.1 \mathrm{~Hz}, 1 \mathrm{H}, \mathrm{NH}), 4.29$ $(\mathrm{dd}, J=12.7,9.6 \mathrm{~Hz}, 1 \mathrm{H}, \mathrm{NH}), 4.11(\mathrm{~s}, 3 \mathrm{H}, \mathrm{NHC} \mathrm{CH}), 3.76\left(\mathrm{~s}, 3 \mathrm{H}, \mathrm{NHC} \mathrm{CH}_{3}\right), 3.19(\mathrm{~s}, 3 \mathrm{H}$, $\left.\mathrm{NHC} \mathrm{CH}_{3}\right), 2.98(\mathrm{~s}, 3 \mathrm{H}, \mathrm{NHC} \mathrm{CH} 3), 2.55-2.41(\mathrm{~m}, 1 \mathrm{H}, \alpha \mathrm{CH}), 1.23\left(\mathrm{~d}, J=7.0 \mathrm{~Hz}, 3 \mathrm{H}\right.$, ala $\left.\mathrm{CH}_{3}\right)$, -24.00 (s, 1H, hydride). ${ }^{13} \mathrm{C}$ NMR (101 MHz, DMSO- $\left.d_{6}, \delta\right): 179.9(C(\mathrm{O})), 149.0$ (C carbene), 142.1 ( $\left.\mathrm{C}_{\text {carbene }}\right), 123.3$ (NHC backbone), 123.2 (NHC backbone), 122.8 (NHC backbone), 122.7 (NHC backbone), $53.7(\alpha \mathrm{C}), 38.6\left(\mathrm{NHC} \mathrm{CH}_{3}\right), 38.2\left(\mathrm{NHC} \mathrm{CH}_{3}\right), 36.8\left(\mathrm{NHC} \mathrm{CH}_{3}\right), 35.2$ $\left(\mathrm{NHC} \mathrm{CH}_{3}\right), 20.6\left(\right.$ ala $\left.\mathrm{CH}_{3}\right)$. Analysis for minor isomer $(49 \%):{ }^{1} \mathbf{H}$ NMR $\left(400 \mathrm{MHz}, \mathrm{DMSO}-d_{6}\right.$, $\delta): 7.34(\mathrm{~d}, J=2.0 \mathrm{~Hz}, 1 \mathrm{H}, \mathrm{NHC}$ backbone), $7.32(\mathrm{~d}, J=2.0 \mathrm{~Hz}, 1 \mathrm{H}, \mathrm{NHC}$ backbone), 7.25 (d, $J=1.9 \mathrm{~Hz}, 1 \mathrm{H}, \mathrm{NHC}$ backbone), $7.24(\mathrm{~d}, J=1.9 \mathrm{~Hz}, 1 \mathrm{H}, \mathrm{NHC}$ backbone), 5.59 (dd, $J=$ 11.6, $5.1 \mathrm{~Hz}, 1 \mathrm{H}, \mathrm{NH}), 4.52(\mathrm{t}, J=11.4 \mathrm{~Hz}, 1 \mathrm{H}, \mathrm{NH}), 4.06(\mathrm{~s}, 3 \mathrm{H}, \mathrm{NHC} \mathrm{CH}), 3.94(\mathrm{~s}, 3 \mathrm{H}$, $\mathrm{NHC} \mathrm{CH}_{3}$ ), 3.41 (ddt, $\left.J=13.9,10.0,6.9 \mathrm{~Hz}, 1 \mathrm{H}, \alpha \mathrm{CH}\right), 3.18(\mathrm{~s}, 3 \mathrm{H}, \mathrm{NHC} \mathrm{CH}$ ) , $2.86(\mathrm{~s}, 3 \mathrm{H}$, $\left.\mathrm{NHC} \mathrm{CH}_{3}\right), 1.14\left(\mathrm{~d}, \mathrm{~J}=6.9 \mathrm{~Hz}, 3 \mathrm{H}\right.$, Ala $\left.\mathrm{CH}_{3}\right),-24.23\left(\mathrm{~s}, 1 \mathrm{H}\right.$, hydride). ${ }^{13} \mathrm{CNMR}(101 \mathrm{MHz}$, DMSO- $\left.d_{6}, \delta\right): 179.0(C(\mathrm{O})), 149.0\left(\mathrm{C}_{\text {carbene }}\right), 143.6\left(\mathrm{C}_{\text {carbene }}\right), 123.8$ (NHC backbone $), 123.3$ (NHC backbone), 122.9 (NHC backbone), 122.8 (NHC backbone), $53.3(\alpha \mathrm{C}), 38.7$ (NHC $\left.\mathrm{CH}_{3}\right), 38.3\left(\mathrm{NHC} \mathrm{CH}_{3}\right), 36.6\left(\mathrm{NHC} \mathrm{CH}_{3}\right), 34.9\left(\mathrm{NHC} \mathrm{CH}_{3}\right), 20.0\left(\mathrm{Ala} \mathrm{CH}_{3}\right)$. HRMS/ESI+ $(\mathrm{m} / z)$ : Calc. for $\mathrm{C}_{13} \mathrm{H}_{23} \mathrm{O}_{2}\left[{ }^{193} \mathrm{Ir}\right] \mathrm{N}_{5}$ : 474.1476; Found: 474.1455 .

\subsubsection{Synthesis of $\operatorname{Ir}(\mathrm{IMe})_{2}(\mathrm{~L}-\mathrm{Val})(\mathrm{H})(\mathrm{I})$}

Following the general procedure: $\left[\operatorname{Ir}(\mathrm{COD})(\mathrm{IMe})_{2}\right] \mathrm{I}(0.2000 \mathrm{~g}, 0.3228 \mathrm{mmol})$ and Lvaline $(0.0756 \mathrm{~g}, 0.6456 \mathrm{mmol})$ were reacted in water to give $\operatorname{Ir}(\mathrm{IMe})_{2}(\mathrm{~L}-\mathrm{Val})(\mathrm{H})(\mathrm{I})(0.1756 \mathrm{~g}$, $87 \%$ ). Analysis for major isomer (55\%): ${ }^{1} \mathbf{H}$ NMR (400 MHz, DMSO- $\left.d_{6}, \delta\right): 7.44(\mathrm{~d}, J=2.0 \mathrm{~Hz}$, $1 \mathrm{H}, \mathrm{NHC}$ backbone), 7.36 (d, J = 2.0 Hz, 1H, NHC backbone), 7.28 (d, J = 2.0 Hz, 1H, NHC backbone), $7.26(\mathrm{~d}, J=2.0 \mathrm{~Hz}, 2 \mathrm{H}, \mathrm{NHC}$ backbone), $4.78(\mathrm{dd}, J=12.5,6.2 \mathrm{~Hz}, 1 \mathrm{H}, \mathrm{NH})$,

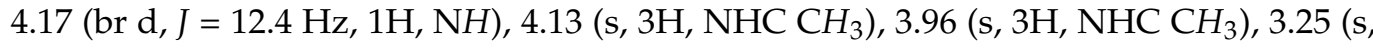
$3 \mathrm{H}, \mathrm{NHC} \mathrm{CH}$ ), 3.10 (s, 3H, NHC CH 3 ), 2.32 (ddd, $J=11.2,6.0,3.1 \mathrm{~Hz}, 1 \mathrm{H}, \alpha \mathrm{CH}), 2.13$ $(\mathrm{ddp}, J=9.9,6.9,3.5 \mathrm{~Hz}, 1 \mathrm{H}, \mathrm{Val} \mathrm{CH}), 0.93(\mathrm{~d}, J=7.1 \mathrm{~Hz}, 3 \mathrm{H}, \mathrm{Val} \mathrm{CH}), 0.83(\mathrm{~d}, J=6.9 \mathrm{~Hz}$, $3 \mathrm{H}$, Val $\left.\mathrm{CH}_{3}\right),-23.80$ (s, $1 \mathrm{H}$, hydride). ${ }^{13} \mathrm{C}$ NMR $\left(101 \mathrm{MHz}, \mathrm{DMSO}-d_{6}, \delta\right): 178.5(\mathrm{C}(\mathrm{O}))$, 148.0 ( C $\left._{\text {carbene }}\right), 141.2$ ( $\left.\mathrm{C}_{\text {carbene }}\right), 124.0$ (NHC backbone), 123.9 (NHC backbone), 123.0 (NHC backbone), 122.9 (NHC backbone), $62.1(\alpha \mathrm{C}), 38.7\left(\mathrm{NHC} \mathrm{CH}_{3}\right), 38.4\left(\mathrm{NHC} \mathrm{CH}_{3}\right), 36.9(\mathrm{NHC}$ $\left.\mathrm{CH}_{3}\right), 35.3\left(\mathrm{NHC} \mathrm{CH}_{3}\right), 31.5(\mathrm{Val} \mathrm{CH}), 18.4(\mathrm{Val} \mathrm{CH}), 16.9\left(\mathrm{Val} \mathrm{CH}_{3}\right)$. Analysis for minor isomer $(45 \%):{ }^{1} \mathbf{H}$ NMR (400 MHz, DMSO- $\left.d_{6}, \delta\right): 7.45(\mathrm{~d}, J=2.0 \mathrm{~Hz}, 1 \mathrm{H}, \mathrm{NHC}$ backbone), $7.34(\mathrm{~d}, J=2.0 \mathrm{~Hz}, 1 \mathrm{H}, \mathrm{NHC}$ backbone $), 7.31(\mathrm{~d}, J=2.0 \mathrm{~Hz}, 1 \mathrm{H}, \mathrm{NHC}$ backbone $), 7.26(\mathrm{~d}, J=$ $1.7 \mathrm{~Hz}, 2 \mathrm{H}, \mathrm{NHC}$ backbone), $5.43(\mathrm{dd}, J=12.0,6.6 \mathrm{~Hz}, 1 \mathrm{H}, \mathrm{NH}), 4.09\left(\mathrm{~s}, 3 \mathrm{H}, \mathrm{NHC} \mathrm{CH}_{3}\right)$, 
3.89 (s, 3H, NHC CH $\mathrm{NH}_{3}$, 3.23 (s, 3H, $\mathrm{NHC} \mathrm{CH}_{3}$ ), 3.16 (ddd, $J=9.0,6.7,4.5 \mathrm{~Hz}, 1 \mathrm{H}, \alpha \mathrm{CH}$ ), $2.95\left(\mathrm{~s}, 3 \mathrm{H}, \mathrm{NHC} \mathrm{CH} \mathrm{CH}_{3}\right), 2.04(\mathrm{dtd}, J=13.9,6.9,4.5 \mathrm{~Hz}, 1 \mathrm{H}, \mathrm{Val} \mathrm{CH}), 0.90(\mathrm{~d}, J=6.9 \mathrm{~Hz}, 3 \mathrm{H}$, Val $\left.\mathrm{CH}_{3}\right), 0.49(\mathrm{~d}, \mathrm{~J}=6.9 \mathrm{~Hz}, 3 \mathrm{H}, \mathrm{Val} \mathrm{CH}),-23.84\left(\mathrm{~s}, 1 \mathrm{H}\right.$, hydride). ${ }^{13} \mathrm{C}$ NMR $(101 \mathrm{MHz}$, DMSO- $\left.d_{6}, \delta\right): 179.0(C(\mathrm{O})), 149.3$ ( $\left.\mathrm{C}_{\text {carbene }}\right), 142.1$ ( $\left.\mathrm{C}_{\text {carbene }}\right), 123.8$ (NHC backbone), 123.3 (NHC backbone), 123.1 (NHC backbone), 122.9 (NHC backbone), $61.3(\alpha C), 38.6$ (NHC $\left.\mathrm{CH}_{3}\right), 37.5\left(\mathrm{NHC} \mathrm{CH}_{3}\right), 36.8\left(\mathrm{NHC} \mathrm{CH}_{3}\right), 35.2\left(\mathrm{NHC} \mathrm{CH}_{3}\right), 31.0$ (val $\left.\mathrm{CH}\right), 19.3(\mathrm{Val} \mathrm{CH})_{3}$, $16.5\left(\mathrm{Val} \mathrm{CH}_{3}\right)$. HRMS/ESI+ (m/z): Calc. for $\mathrm{C}_{15} \mathrm{H}_{27} \mathrm{O}_{2}\left[{ }^{193} \mathrm{Ir}\right] \mathrm{N}_{5}$ : 502.1789; Found: 502.1777.

\subsection{Synthesis of $\operatorname{Ir}(I M e)_{2}(\mathrm{~L}-\mathrm{Phg})(\mathrm{H})(\mathrm{I})$}

Following the general procedure: $\left[\operatorname{Ir}(\mathrm{COD})(\mathrm{IMe})_{2}\right] \mathrm{I}(0.2000 \mathrm{~g}, 0.3228 \mathrm{mmol})$ and Lphenylglycine $(0.0976 \mathrm{~g}, 0.6456 \mathrm{mmol})$ were reacted in water to give $\operatorname{Ir}(\mathrm{IMe})_{2}(\mathrm{~L}-\mathrm{Phg})(\mathrm{H})(\mathrm{I})$ $(0.1401 \mathrm{~g}, 66 \%)$. Phenyl ${ }^{1} \mathrm{H}$ NMR signals from both isomers ranged from $7.35-7.13$ and overlapped with each other and with the signals for the NHC backbones, while phenyl ${ }^{13} \mathrm{C}$ NMR signals from both isomers ranged from 128.3-127.1 and overlapped with each other. Analysis for major isomer (55\%): ${ }^{1} \mathbf{H}$ NMR (400 MHz, DMSO- $\left.d_{6}, \delta\right): 7.38(\mathrm{~d}, J=2.0 \mathrm{~Hz}$, $1 \mathrm{H}, \mathrm{NHC}$ backbone), 7.31 (dd, $J=2.2,0.7 \mathrm{~Hz}, 2 \mathrm{H}, \mathrm{NHC}$ backbone), $7.21(\mathrm{~d}, J=1.9 \mathrm{~Hz}, 1 \mathrm{H}$, NHC backbone), $6.06(\mathrm{~m}, 1 \mathrm{H}, \mathrm{NH}), 4.66-4.51(\mathrm{~m}, 2 \mathrm{H}$, overlapped $\alpha \mathrm{CH}$ and $\mathrm{NH}), 4.12$ (s,

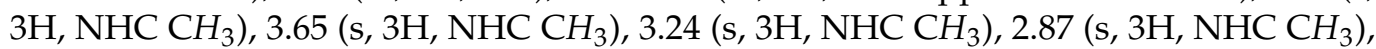
-24.33 (s, 1H, hydride). ${ }^{13} \mathrm{C}$ NMR (101 MHz, DMSO- $\left.d_{6}, \delta\right): 177.0(\mathrm{C}(\mathrm{O})), 148.4\left(\mathrm{C}_{\text {carbene }}\right)$, 142.3 ( $\left.\mathrm{C}_{\text {carbene }}\right), 140.1$ (Ph), 123.3 (NHC backbone), 123.0 (NHC backbone), 122.9 (NHC backbone), 122.8 (NHC backbone), $61.5(\alpha \mathrm{C}), 38.2\left(\mathrm{NHC} \mathrm{CH}_{3}\right), 36.8\left(\mathrm{NHC} \mathrm{CH}_{3}\right), 35.0(\mathrm{NHC}$ $\left.\mathrm{CH}_{3}\right)$. Analysis for minor isomer (45\%): ${ }^{1} \mathbf{H}$ NMR (400 MHz, DMSO- $\left.d_{6}, \delta\right): 7.50(\mathrm{~d}, J=2.0 \mathrm{~Hz}$, $1 \mathrm{H}, \mathrm{NHC}$ backbone), $7.25(\mathrm{~d}, J=1.9 \mathrm{~Hz}, 2 \mathrm{H}, \mathrm{NHC}$ backbone), 7.15 (dd, J = 1.9, $0.5 \mathrm{~Hz}, 1 \mathrm{H}$, NHC backbone), $5.66(\mathrm{dd}, J=12.3,6.6 \mathrm{~Hz}, 1 \mathrm{H}, \mathrm{NH}), 4.78-4.67(\mathrm{~m}, 1 \mathrm{H}, \mathrm{NH}), 4.18(\mathrm{~s}, 3 \mathrm{H}$, $\mathrm{NHC} \mathrm{CH}_{3}$ ), $3.96(\mathrm{~s}, 3 \mathrm{H}, \mathrm{NHC} \mathrm{CH}$ ), $3.61(\mathrm{dd}, J=10.5,6.5 \mathrm{~Hz}, 1 \mathrm{H}, \alpha \mathrm{CH}), 3.33$ (s, overlapped with $\mathrm{H}_{2} \mathrm{O}$ peak, NHC CH $\left.\mathrm{CH}_{3}\right), 3.11$ (s, 3H, NHC CH 3$),-24.04$ (s, 1H, hydride). ${ }^{13} \mathrm{C}$ NMR (101 MHz, DMSO- $\left.d_{6}, \delta\right): 178.1(\mathrm{C}(\mathrm{O})), 147.8$ (C $\left.\mathrm{C}_{\text {carbene }}\right), 141.1$ ( $\left.\mathrm{C}_{\text {carbene }}\right), 141.9(\mathrm{Ph}), 124.0$ (NHC backbone), 123.9 (NHC backbone), 123.4 (NHC backbone), 123.2 (NHC backbone), $61.1(\alpha \mathrm{C}), 38.3\left(\mathrm{NHC} \mathrm{CH}_{3}\right), 37.0\left(\mathrm{NHC} \mathrm{CH}_{3}\right), 35.4\left(\mathrm{NHC} \mathrm{CH}_{3}\right)$. HRMS/ESI+ $(\mathrm{m} / \mathrm{z})$ : Calc. for $\mathrm{C}_{18} \mathrm{H}_{25} \mathrm{O}_{2}\left[{ }^{193} \mathrm{Ir}\right] \mathrm{N}_{5}$ : 536.1632; Found: 536.1636.

\subsubsection{Synthesis of $\operatorname{Ir}(\mathrm{IMe})_{2}(\mathrm{~L}-\mathrm{Aze})(\mathrm{H})(\mathrm{I})$}

Following the general procedure: $\left[\operatorname{Ir}(\mathrm{COD})(\mathrm{IMe})_{2}\right] \mathrm{I}(0.2000 \mathrm{~g}, 0.3228 \mathrm{mmol})$ and Lazetidine-2-carboxylic acid $(0.0653 \mathrm{~g}, 0.6456 \mathrm{mmol})$ were reacted in water to give $\mathrm{Ir}(\mathrm{IMe})_{2}(\mathrm{~L}$ Aze)(H)(I) $\left(0.1088\right.$ g, 55\%). HRMS/ESI+ $(m / z)$ : Calc. for $\mathrm{C}_{14} \mathrm{H}_{23} \mathrm{O}_{2}\left[{ }^{193} \mathrm{Ir}\right] \mathrm{N}_{5}$ : 486.1476; Found: 486.1476. Due to the presence of many isomers (that could not be separated by column chromatography) and overlapping resonances, the NMR spectra were not assigned for this structure. Additional characterization was not further pursued due to poor catalytic enantioselectivity.

\subsubsection{Synthesis of $\operatorname{Ir}(\mathrm{IMe})_{2}$ (L-Pro)(H)(I)}

Following the general procedure: $\left[\operatorname{Ir}(\mathrm{COD})(\mathrm{IMe})_{2}\right] \mathrm{I}(0.2000 \mathrm{~g}, 0.3228 \mathrm{mmol})$ and Lproline $(0.0743 \mathrm{~g}, 0.6456 \mathrm{mmol})$ were reacted in water to give $\operatorname{Ir}(\mathrm{IMe})_{2}$ (L-Pro)(H)(I) $(0.1861$ g, 92\%). ${ }^{1} \mathbf{H}$ NMR $(400 \mathrm{MHz}$, DMSO-d $6, \delta): 7.42$ (d, $J=1.9 \mathrm{~Hz}, 1 \mathrm{H}$, NHC backbone), 7.35 (d, $J=2.0 \mathrm{~Hz}, 1 \mathrm{H}$, NHC backbone), $7.31(\mathrm{~d}, J=2.0 \mathrm{~Hz}, 1 \mathrm{H}, \mathrm{NHC}$ backbone), 7.25 (d, $J=2.0$ $\mathrm{Hz}, 1 \mathrm{H}, \mathrm{NHC}$ backbone), $5.97(\mathrm{dt}, J=10.7,5.5 \mathrm{~Hz}, 1 \mathrm{H}, \mathrm{NH}), 4.09$ (s, 3H, NHC CH $)_{3}, 3.94$ $\left.(\mathrm{s}, 3 \mathrm{H}, \mathrm{NHC} \mathrm{CH})_{3}\right), 3.63(\mathrm{dd}, J=8.6,5.5 \mathrm{~Hz}, 1 \mathrm{H}, \alpha \mathrm{CH}), 3.31\left(\mathrm{~s}, 3 \mathrm{H}, \mathrm{NHC} \mathrm{CH}_{3}\right), 3.00(\mathrm{~s}, 3 \mathrm{H}$, $\left.\mathrm{NHC} \mathrm{CH}_{3}\right), 2.02\left(\mathrm{dq}, J=12.9,8.0 \mathrm{~Hz}, 1 \mathrm{H}\right.$, Pro $\left.\mathrm{CH}_{2}\right), 1.93(\mathrm{ddd}, J=17.9,8.9,4.7 \mathrm{~Hz}, 1 \mathrm{H}$, Pro $\left.\mathrm{CH}_{2}\right), 1.77\left(\mathrm{dt}, J=13.3,7.1 \mathrm{~Hz}, 1 \mathrm{H}\right.$, Pro $\left.\mathrm{CH}_{2}\right), 1.69\left(\mathrm{t}, J=7.5 \mathrm{~Hz}, 1 \mathrm{H}\right.$, Pro $\left.\mathrm{CH}_{2}\right), 1.64-1.55$ $\left(\mathrm{m}, 1 \mathrm{H}\right.$, Pro $\left.\mathrm{CH}_{2}\right), 1.49$ (qd, $J=11.6,7.2 \mathrm{~Hz}, 1 \mathrm{H}$, Pro $\left.\mathrm{CH}_{2}\right),-24.12$ (s, $1 \mathrm{H}$, hydride). ${ }^{13} \mathrm{C}$ NMR (101 MHz, DMSO- $\left.d_{6}, \delta\right): 178.9(\mathrm{C}(\mathrm{O})), 150.0\left(\mathrm{C}_{\text {carbene }}\right), 140.2\left(\mathrm{C}_{\text {carbene }}\right), 123.9$ (NHC backbone), 123.6 (NHC backbone), 123.3 (NHC backbone), 122.6 (NHC backbone), 60.7 (Pro $\alpha \mathrm{CH}), 52.4\left(\operatorname{Pro} \mathrm{CH}_{2}\right), 39.8\left(\mathrm{NHC} \mathrm{CH}_{3}\right), 38.3\left(\mathrm{NHC} \mathrm{CH}_{3}\right), 36.8\left(\mathrm{NHC} \mathrm{CH}_{3}\right), 35.4\left(\mathrm{NHC} \mathrm{CH}_{3}\right)$, 
28.9 (Pro $\left.\mathrm{CH}_{2}\right)$, $24.1\left(\right.$ Pro $\left.\mathrm{CH}_{2}\right)$. HRMS/ESI+ $(\mathrm{m} / \mathrm{z})$ : Calc. for C15H25O2[ $\left.{ }^{193} \mathrm{Ir}\right] \mathrm{N5}$ : 500.1632; Found: 500.1624 .

\subsubsection{Synthesis of $\operatorname{Ir}(\mathrm{IMe})_{2}$ (D-Pro)(H)(I)}

Following the general procedure: $\left[\operatorname{Ir}(\mathrm{COD})(\mathrm{IMe})_{2}\right] \mathrm{I}(0.2000 \mathrm{~g}, 0.3228 \mathrm{mmol})$ and Dproline $(0.0743 \mathrm{~g}, 0.6456 \mathrm{mmol})$ were reacted in water to give $\operatorname{Ir}(\mathrm{IMe})_{2}$ (D-Pro)(H)(I) $(0.1450 \mathrm{~g}$, 72\%). HRMS/ESI+ (m/z): Calc. for $\mathrm{C}_{15} \mathrm{H}_{25} \mathrm{O}_{2}\left[{ }^{193} \mathrm{Ir}\right] \mathrm{N}_{5}$ : 500.1632; Found: 500.1631. NMR spectra were identical to $\operatorname{Ir}(\mathrm{IMe})_{2}(\mathrm{~L}-\mathrm{Pro})(\mathrm{H})(\mathrm{I})$.

\subsubsection{Synthesis of $\operatorname{Ir}(\mathrm{IMe})_{2}$ (L-F-Pro)(H)(I)}

Following the general procedure: $\left[\operatorname{Ir}(\mathrm{COD})(\mathrm{IMe})_{2}\right] \mathrm{I}(0.2000 \mathrm{~g}, 0.3228 \mathrm{mmol})$ and cis4-fluoro-L-proline $(0.0859 \mathrm{~g}$, $0.6456 \mathrm{mmol})$ were reacted in water to give $\operatorname{Ir}(\mathrm{IMe})_{2}$ (L-FPro)(H)(I) $(0.0921 \mathrm{~g}, 44 \%) .{ }^{1} \mathbf{H}$ NMR $\left(400 \mathrm{MHz}\right.$, DMSO- $\left.d_{6}, \delta\right): 7.41(\mathrm{~d}, J=1.9 \mathrm{~Hz}, 1 \mathrm{H}, \mathrm{NHC}$ backbone), 7.35 (d, $J=1.9 \mathrm{~Hz}, 1 \mathrm{H}, \mathrm{NHC}$ backbone), 7.31 (d, $J=1.9 \mathrm{~Hz}, 1 \mathrm{H}, \mathrm{NHC}$ backbone), $7.26(\mathrm{~d}, J=2.0 \mathrm{~Hz}, 1 \mathrm{H}, \mathrm{NHC}$ backbone), $6.42(\mathrm{dt}, J=11.5,5.4 \mathrm{~Hz}, 1 \mathrm{H}, \mathrm{NH}), 5.28-4.96(\mathrm{tm}, J=$ 112.1, 53.9, $1 \mathrm{H}, \mathrm{FCH}), 4.14(\mathrm{dd}, J=11.4,5.1 \mathrm{~Hz}, 1 \mathrm{H}, \alpha \mathrm{CH}), 4.09\left(\mathrm{~s}, 3 \mathrm{H}, \mathrm{NHC} \mathrm{CH}_{3}\right), 4.06-3.98$ $\left(\mathrm{m}, 1 \mathrm{H}\right.$, Pro $\left.\mathrm{CH}_{2}\right), 3.96\left(\mathrm{~s}, 3 \mathrm{H}, \mathrm{NHC} \mathrm{CH}_{3}\right), 3.34\left(\mathrm{~s}, 3 \mathrm{H}, \mathrm{NHC} \mathrm{CH}_{3}\right), 3.00\left(\mathrm{~s}, 3 \mathrm{H}, \mathrm{NHC} \mathrm{CH} \mathrm{CH}_{3}\right.$, 2.35-2.15 (m, 2H, proline $\left.\mathrm{CH}_{2}\right), 1.79$ (app dtd, $J=25.4,13.3,3.71 \mathrm{H}$, Pro $\left.\mathrm{CH}_{2}\right),-24.19(\mathrm{~s}, 1 \mathrm{H}$, hydride). ${ }^{13} \mathrm{C}$ NMR (400 MHz, DMSO- $\left.d_{6}, \delta\right): 149.3$ (C $\left.\mathrm{C}_{\text {carbene }}\right), 138.9$ ( $\left.\mathrm{C}_{\text {carbene }}\right), 124.1$ (NHC backbone), 123.7 (NHC backbone), 123.4 (NHC backbone), 122.7 (NHC backbone), 93.9 $(\mathrm{d}, J=174.8 \mathrm{~Hz}$, Pro $C \mathrm{~F}), 63.4$ (Pro $\alpha \mathrm{CH}), 62.0\left(\mathrm{~d}, J=18.5 \mathrm{~Hz}\right.$, Pro $\left.\mathrm{CH}_{2}\right), 38.4\left(\mathrm{NHC} \mathrm{CH}_{3}\right)$, $37.5\left(\mathrm{NHC} \mathrm{CH}_{3}\right), 36.9\left(\mathrm{NHC} \mathrm{CH}_{3}\right), 35.5\left(\mathrm{NHC} \mathrm{CH}_{3}\right), 35.4\left(\right.$ Pro $\left.\mathrm{CH}_{2}\right),{ }^{19} \mathbf{F}$ NMR $(376 \mathrm{MHz}$, DMSO- $\left.d_{6}, \delta\right):-169.18--173.96(\mathrm{~m})$. HRMS/ESI+ $(\mathrm{m} / \mathrm{z})$ : Calc. for $\mathrm{C}_{15} \mathrm{H}_{24} \mathrm{FO}_{2}\left[{ }^{193} \mathrm{Ir}\right] \mathrm{N}_{5}$ : 518.1543; Found: 518.1503.

\subsubsection{Synthesis of $\operatorname{Ir}(\mathrm{IMe})_{2}(\mathrm{~L}-\mathrm{Pip})(\mathrm{H})(\mathrm{I})$}

Following the general procedure: $\left[\operatorname{Ir}(\mathrm{COD})(\mathrm{IMe})_{2}\right] \mathrm{I}(0.2000 \mathrm{~g}, 0.3228 \mathrm{mmol})$ and Lpipecolic acid $(0.0834 \mathrm{~g}, 0.6456 \mathrm{mmol})$ were reacted in water to give $\operatorname{Ir}(\mathrm{IMe})_{2}(\mathrm{~L}-\mathrm{Pip})(\mathrm{H})(\mathrm{I})$ $(0.1359 \mathrm{~g}, 66 \%)$. HRMS/ESI+ (m/z): Calc. for $\mathrm{C}_{16} \mathrm{H}_{27} \mathrm{O}_{2}\left[{ }^{193} \mathrm{Ir}\right] \mathrm{N}_{5}$ : 514.1789; Found: 514.1783 . Due to the presence of many isomers (that could not be separated by column chromatography) and overlapping resonances, the NMR spectra were not assigned for this structure. Additional characterization was not further pursued due to poor catalytic enantioselectivity.

\subsubsection{Synthesis of $\operatorname{Ir}(\mathrm{IEt})_{2}$ (L-Pro)(H)(I)}

Following the general procedure: $\left[\operatorname{Ir}(\mathrm{COD})(\mathrm{IEt})_{2}\right] \mathrm{I}(0.2000 \mathrm{~g}, 0.2960 \mathrm{mmol})$ and $\mathrm{L}-$ proline $(0.0682 \mathrm{~g}, 0.5920 \mathrm{mmol})$ were reacted in water to give $\operatorname{Ir}(\mathrm{IEt})_{2}(\mathrm{~L}-\mathrm{Pro})(\mathrm{H})(\mathrm{I})(0.1369 \mathrm{~g}$, 68\%). HRMS/ESI+ (m/z): Calc. for $\mathrm{C}_{19} \mathrm{H}_{33} \mathrm{O}_{2}\left[{ }^{193} \mathrm{Ir}\right] \mathrm{N}_{5}$ : 556.2259; Found: 556.2249. Due to the presence of many isomers (that could not be separated by column chromatography) and overlapping resonances, the NMR spectra were not assigned for this structure. Additional characterization was not further pursued due to poor catalytic enantioselectivity.

\subsubsection{Synthesis of $\operatorname{Ir}\left(\mathrm{I}^{i} \mathrm{Pr}\right)_{2}(\mathrm{~L}-\mathrm{Pro})(\mathrm{H})(\mathrm{Cl})$}

Following the general procedure: $\left[\operatorname{Ir}(\mathrm{COD})\left(\mathrm{I}^{i} \mathrm{Pr}\right)_{2}\right] \mathrm{Cl}(0.2000 \mathrm{~g}, 0.2960 \mathrm{mmol})$ and L-proline $(0.0682 \mathrm{~g}, 0.5920 \mathrm{mmol})$ were reacted in water to give $\operatorname{Ir}\left(\mathrm{I}^{i} \mathrm{Pr}\right)_{2}(\mathrm{~L}-\mathrm{Pro})(\mathrm{H})(\mathrm{Cl})$ $(0.1580 \mathrm{~g}, 82 \%)$. HRMS/ESI+ (m/z): Calc. for $\mathrm{C}_{23} \mathrm{H}_{41} \mathrm{O}_{2}\left[{ }^{193} \mathrm{Ir}\right] \mathrm{N}_{5}$ : 612.2885; Found: 612.2887 . Due to the presence of many isomers (that could not be separated by column chromatography) and overlapping resonances, the NMR spectra were not assigned for this structure. Additional characterization was not further pursued due to poor catalytic enantioselectivity.

\subsection{General Procedure for Asymmetric Transfer Hydrogenation of Ketones}

Using the optimized reaction conditions, the catalyst $(0.005 \mathrm{mmol})$ was dissolved in $2 \mathrm{~mL}$ of isopropyl alcohol and stirred at $25^{\circ} \mathrm{C}$. Catalysis was initiated by addition of the desired substrate $(0.200 \mathrm{mmol})$ and $\mathrm{NaOH}$ (2 equiv.), and maintained at $25{ }^{\circ} \mathrm{C}$ for the appropriate period of time (usually $24 \mathrm{~h}$ ). When initially screening ATH substrates, 
the products were isolated for characterization via NMR spectroscopy to confirm their structures. Isopropyl alcohol was removed by rotary evaporation and water was added to the reaction vial. The products were then extracted with diethyl ether, and dried over magnesium sulfate. Following filtration and solvent removal under vacuum, the ${ }^{1} \mathrm{H}$ and ${ }^{13} \mathrm{C}$ NMR spectra of all products were acquired, and consistent with previously reported data.

Conversion and enantiomeric excess were determined by chiral GC-FID using a CP-ChiraSil-Dex CB $25 \mathrm{~m} \times 0.25 \mathrm{~mm}$ column (inlet temp $=240{ }^{\circ} \mathrm{C}$, detector temp $=$ $250{ }^{\circ} \mathrm{C}$.) For quantification, 1,3,5-trimethoxybenzene was employed as an internal standard. Absolute configurations of the products were assigned by using the appropriate alcohol standard. Column temperatures are provided with the respective GC chromatograms in the Supplemental Information.

\section{Conclusions}

Novel complexes of the form $\operatorname{Ir}(\mathrm{NHC})_{2}(\mathrm{aa})(\mathrm{H})(\mathrm{X})$ were synthesized by oxidative addition of $\alpha$-amino acids to $\left[\operatorname{Ir}(\mathrm{COD})(\mathrm{NHC})_{2}\right] \mathrm{X}$ precursors and screened for asymmetric transfer hydrogenation of ketones. Following optimization, high enantioselectivity was achieved when employing the $\operatorname{Ir}(\mathrm{IMe})_{2}(\mathrm{~L}-\mathrm{Pro})(\mathrm{H})(\mathrm{I})$ catalyst, which reduces a range of acetophenone derivatives in up to $95 \%$ ee. These results are comparable to other wellregarded ATH catalysts previously reported in the literature, and superior to many of those featuring NHC ligands. This work illustrates the design of highly enantioselective noble metal catalysts by incorporation of inexpensive, "off-the-shelf" chiral amino acids in combination with easily accessible $\mathrm{N}$-heterocyclic carbenes; thus, providing an alternative to costly or synthetically challenging chiral ligands. The facile modularity of this catalytic system may also allow for simple tailoring towards additional ATH substrates, such as alkyl ketones, and potentially other enantioselective transformations.

Supplementary Materials: The following are available online at https://www.mdpi.com/article/ 10.3390/catal11060671/s1, Figure S1: Displacement ellipsoid plot of $\operatorname{Ir}(\mathrm{IMe})_{2}(\mathrm{Gly})(\mathrm{H})(\mathrm{I})$, Table S1: Selected bond lengths and angles from the structure of $\operatorname{Ir}(\mathrm{IMe})_{2}(\mathrm{Gly})(\mathrm{H})(\mathrm{I})$, Figure S2: NMR spectra of $\operatorname{Ir}(\mathrm{IMe})_{2}(\mathrm{Gly})(\mathrm{H})(\mathrm{I})$, Figure S3: NMR spectra of the major isomer of $\operatorname{Ir}(\mathrm{IMe})_{2}(\mathrm{~L}-\mathrm{Ala})(\mathrm{H})(\mathrm{I})$, Figure S4: NMR spectra of the minor isomer of $\operatorname{Ir}(\mathrm{IMe})_{2}(\mathrm{~L}-\mathrm{Ala})(\mathrm{H})(\mathrm{I})$, Figure S5: NMR spectra of the major isomer of $\operatorname{Ir}(\mathrm{IMe})_{2}(\mathrm{~L}-\mathrm{Val})(\mathrm{H})(\mathrm{I})$, Figure S6: NMR spectra of the minor isomer of $\operatorname{Ir}(\mathrm{IMe})_{2}(\mathrm{~L}-\mathrm{Val})(\mathrm{H})(\mathrm{I})$, Figure S7: NMR spectra of the major isomer of $\operatorname{Ir}(\mathrm{IMe})_{2}(\mathrm{~L}-\mathrm{Phg})(\mathrm{H})(\mathrm{I})$, Figure S8: NMR spectra of the minor isomer of $\operatorname{Ir}(\mathrm{IMe})_{2}(\mathrm{~L}-\mathrm{Phg})(\mathrm{H})(\mathrm{I})$, Figure S9: NMR spectra of $\operatorname{Ir}(\mathrm{IMe})_{2}(\mathrm{~L}-\mathrm{Pro})(\mathrm{H})(\mathrm{I})$, Figure S10: NMR spectra of $\operatorname{Ir}(\mathrm{IMe})_{2}$ (L-F-Pro)(H)(I), Figure S11: FID trace of 1-phenylethanol, Figure S12: FID trace of 1-phenylpropanol, Figure S13: FID trace of 2-methyl-1-phenylpropanol, Figure S14: FID trace of 2,2-dimethyl-1-phenylpropanol, Figure S15: FID trace of cyclohexyl(phenyl)methanol, Figure S16: FID trace of 1-(p-tolyl)ethanol, Figure S17: FID trace of 1-(4-fluorophenyl)ethanol, Figure S18: FID trace of 1-(4-(trifluoromethyl)phenyl)ethanol, Figure S19: FID trace of 1-(4-chlorophenyl)ethanol. In addition, CSD number 2062242 contains the full supplementary .cif files for this paper. This data can be obtained free of charge from the Cambridge Crystallographic Data Centre via www.ccdc.cam.ac.uk/structures (accessed on 23 May 2021).

Author Contributions: Conceptualization, J.S.M.; Data curation, C.M.B.; Funding acquisition, J.S.M.; Investigation, C.M.B.; Methodology, C.M.B.; Supervision, J.S.M.; Writing—original draft, C.M.B.; Writing-review \& editing, C.M.B. and J.S.M. All authors have read and agreed to the published version of the manuscript.

Funding: Funding for the Rigaku Oxford Diffraction Synergy diffractometer used in this work was provided by the National Science Foundation (grant No. 1726077).

Acknowledgments: The authors would like to acknowledge Christine M. DuChane, Justin Martinez, and William Owen for providing assistance in synthesis and characterization of the ligands and complexes.

Conflicts of Interest: The authors declare no conflict of interest. 


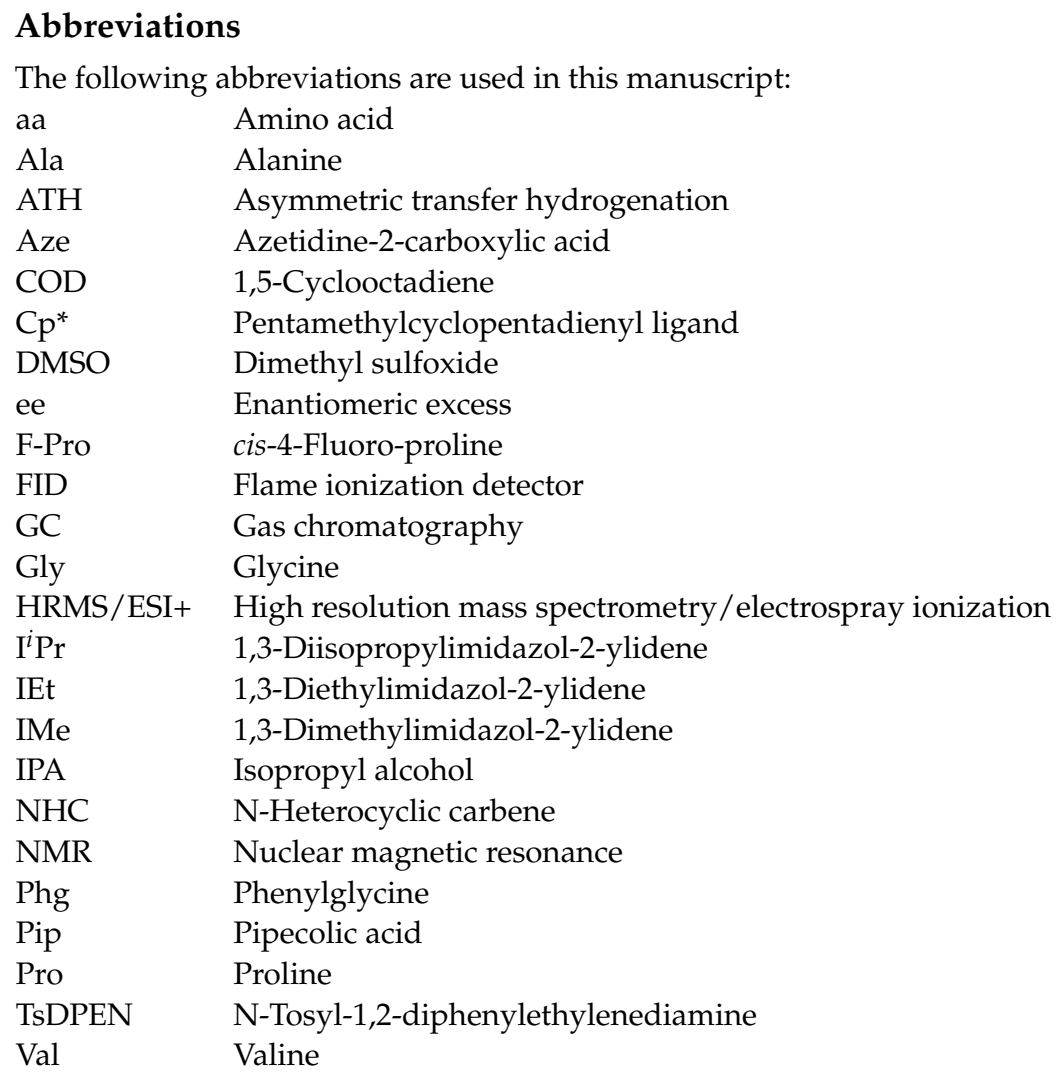

\section{References}

1. Breuer, M.; Ditrich, K.; Habicher, T.; Hauer, B.; Keßeler, M.; Stürmer, R.; Zelinski, T. Industrial methods for the production of optically active intermediates. Angew. Chem. Int. Ed. 2004, 43, 788-824. [CrossRef] [PubMed]

2. Wang, D.; Astruc, D. The golden age of transfer hydrogenation. Chem. Rev. 2015, 115, 6621-6686. [CrossRef]

3. Hashiguchi, S.; Fujii, A.; Takehara, J.; Ikariya, T.; Noyori, R. Asymmetric transfer hydrogenation of aromatic ketones catalyzed by chiral ruthenium(II) complexes. J. Am. Chem. Soc. 1995, 117, 7562-7563. [CrossRef]

4. Fujii, A.; Hashiguchi, S.; Uematsu, N.; Ikariya, T.; Noyori, R. Ruthenium(II)-catalyzed asymmetric transfer hydrogenation of ketones using a formic acid-Triethylamine mixture. J. Am. Chem. Soc. 1996, 118, 2521-2522. [CrossRef]

5. Noyori, R.; Hashiguchi, S. Asymmetric transfer hydrogenation catalyzed by chiral ruthenium complexes. Acc. Chem. Res. 1997, 30, 97-102. [CrossRef]

6. Noyori, R. Asymmetric catalysis: Science and opportunities (Nobel lecture). Angew. Chem. Int. Ed. 2002, 41, 2008. [CrossRef]

7. Yamakawa, M.; Ito, H.; Noyori, R. The metal-ligand bifunctional catalysis: A theoretical study on the ruthenium(II)-catalyzed hydrogen transfer between alcohols and carbonyl compounds. J. Am. Chem. Soc. 2000, 122, 1466-1478. [CrossRef]

8. Noyori, R.; Yamakawa, M.; Hashiguchi, S. Metal-ligand bifunctional catalysis: A nonclassical mechanism for asymmetric hydrogen transfer between alcohols and carbonyl compounds. J. Org. Chem. 2001, 66, 7931-7944. [CrossRef] [PubMed]

9. Clapham, S.E.; Hadzovic, A.; Morris, R.H. Mechanisms of the H2-hydrogenation and transfer hydrogenation of polar bonds catalyzed by ruthenium hydride complexes. Coord. Chem. Rev. 2004, 248, 2201-2237. [CrossRef]

10. Samec, J.S.M.; Bäckvall, J.E.; Andersson, P.G.; Brandt, P. Mechanistic aspects of transition metal-catalyzed hydrogen transfer reactions. Chem. Soc. Rev. 2006, 35, 237. [CrossRef] [PubMed]

11. Eisenstein, O.; Crabtree, R.H. Outer sphere hydrogenation catalysis. New J. Chem. 2013, 37, 21-27. [CrossRef]

12. Ikariya, T.; Blacker, A.J. Asymmetric transfer hydrogenation of ketones with bifunctional transition metal-based molecular catalysts. Acc. Chem. Res. 2007, 40, 1300-1308. [CrossRef] [PubMed]

13. Khusnutdinova, J.R.; Milstein, D. Metal-ligand cooperation. Angew. Chem. Int. Ed. 2015, 54, 12236-12273. [CrossRef] [PubMed]

14. Dub, P.A.; Gordon, J.C. Metal-Ligand bifunctional catalysis: The "accepted" mechanism, the issue of concertedness, and the function of the ligand in catalytic cycles involving hydrogen atoms. ACS Catal. 2017, 7, 6635-6655. [CrossRef]

15. Dub, P.A.; Gordon, J.C. The role of the metal-bound N-H functionality in Noyori-type molecular catalysts. Nat. Rev. Chem. 2018, 2, 396-408. [CrossRef]

16. Agbossou-Niedercorn, F.; Michon, C. Bifunctional homogeneous catalysts based on first row transition metals in asymmetric hydrogenation. Coord. Chem. Rev. 2020, 425, 213523. [CrossRef] 
17. Gladiali, S.; Alberico, E. Asymmetric transfer hydrogenation: Chiral ligands and applications. Chem. Soc. Rev. 2006, 35, 226-236. [CrossRef] [PubMed]

18. Wang, C.; Wu, X.; Xiao, J. Broader, greener, and more efficient: Recent advances in asymmetric transfer hydrogenation. Chem. Asian J. 2008, 3, 1750-1770. [CrossRef] [PubMed]

19. Stefane, B.; Pozgan, F. Asymmetric hydrogenation and transfer hydrogenation of ketones. In Hydrogenation; Karame, I., Ed.; InTechOpen: London, UK, 2012; Chapter 2. [CrossRef]

20. Foubelo, F.; Nájera, C.; Yus, M. Catalytic asymmetric transfer hydrogenation of ketones: Recent advances. Tetrahedron Asymmetry 2015, 26, 769-790. [CrossRef]

21. Baráth, E. Hydrogen transfer reactions of carbonyls, alkynes, and alkenes with noble metals in the presence of alcohols/ethers and amines as hydrogen donors. Catalysts 2018, 8, 671. [CrossRef]

22. Matsunami, A.; Kayaki, Y. Upgrading and expanding the scope of homogeneous transfer hydrogenation. Tetrahedron Lett. 2018, 59, 504-513. [CrossRef]

23. Seo, C.S.G.; Morris, R.H. Catalytic homogeneous asymmetric hydrogenation: Successes and opportunities. Organometallics 2019, 38, 47-65. [CrossRef]

24. Ohta, T.; Nakahara, S.I.; Shigemura, Y.; Hattori, K.; Furukawa, I. $\alpha$-Amino acid: An effective ligand for asymmetric catalysis of transfer hydrogenation of ketones. Appl. Organomet. Chem. 2001, 15, 699-709. [CrossRef]

25. Carmona, D.; Lamata, M.P.; Oro, L.A. Half-sandwich complexes with aminocarboxylate ligands and their use as enantioselective hydrogen transfer catalysts. Eur. J. Inorg. Chem. 2002, 2002, 2239-2251. [CrossRef]

26. Yim, A.S.; Wills, M. Asymmetric transfer hydrogenation using amino acid derivatives; further studies and a mechanistic proposal. Tetrahedron 2005, 61, 7994-8004. [CrossRef]

27. Ahlford, K.; Ekström, J.; Zaitsev, A.B.; Ryberg, P.; Eriksson, L.; Adolfsson, H. Asymmetric transfer hydrogenation of ketones catalyzed by amino acid derived rhodium complexes: On the origin of enantioselectivity and enantioswitchability. Chem. Eur. J. 2009, 15, 11197-11209. [CrossRef] [PubMed]

28. Paradowska, J.; Stodulski, M.; Mlynarski, J. Catalysts based on amino acids for asymmetric reactions in water. Angew. Chem. Int. Ed. 2009, 48, 4288-4297. [CrossRef] [PubMed]

29. Nordin, M.; Liao, R.Z.; Ahlford, K.; Adolfsson, H.; Himo, F. Theoretical study of asymmetric transfer hydrogenation of ketones catalyzed by amino acid-derived rhodium complexes. Chem CatChem 2012, 4, 1095-1104. [CrossRef]

30. Carmona, D.; Lahoz, F.J.; García-Orduña, P.; Oro, L.A.; Lamata, M.P.; Viguri, F. Half-sandwich complexes of osmium(II) with L- $\alpha-$ amino carboxylate ligands as asymmetric transfer hydrogenation catalysts. On the origin of the enantioselectivity. Organometallics 2012, 31, 3333-3345. [CrossRef]

31. Carmona, D.; Viguri, F.; Pilar Lamata, M.; Ferrer, J.; Bardají, E.; Lahoz, F.J.; García-Orduña, P.; Oro, L.A. Ruthenium amino carboxylate complexes as asymmetric hydrogen transfer catalysts. Dalton Trans. 2012, 41, 10298. [CrossRef] [PubMed]

32. Biancalana, L.; Abdalghani, I.; Chiellini, F.; Zacchini, S.; Pampaloni, G.; Crucianelli, M.; Marchetti, F. Ruthenium arene complexes with $\alpha$-aminoacidato ligands: New insights into transfer hydrogenation reactions and cytotoxic behaviour. Eur. J. Inorg. Chem. 2018, 2018, 3041-3057. [CrossRef]

33. Morris, D.M.; McGeagh, M.; De Peña, D.; Merola, J.S. Extending the range of pentasubstituted cyclopentadienyl compounds: The synthesis of a series of tetramethyl(alkyl or aryl)cyclopentadienes $\left(\mathrm{C} \mathrm{p}^{*} \mathrm{R}\right)$, their iridium complexes and their catalytic activity for asymmetric transfer hydrogenation. Polyhedron 2014, 84, 120-135. [CrossRef]

34. Morris, D.M. Design and Modification of Half-Sandwich Ir(III), Rh(III), and Ru(II) Amino acid Complexes for Application in Asymmetric Transfer Hydrogenation Reactions. Ph.D. Thesis, Virginia Tech, Blacksburg, VA, USA 2015.

35. Herrmann, W.A. N-heterocyclic carbenes: A new concept in organometallic catalysis. Angew. Chem. Int. Ed. 2002, 41, 1290-1309. [CrossRef]

36. Hopkinson, M.N.; Richter, C.; Schedler, M.; Glorius, F. An overview of N-heterocyclic carbenes. Nat. Chem. 2014, 510, 485-496. [CrossRef]

37. César, V.; Bellemin-Laponnaz, S.; Gade, L.H. Chiral N-heterocyclic carbenes as stereodirecting ligands in asymmetric catalysis. Chem. Soc. Rev. 2004, 33, 619-636. [CrossRef] [PubMed]

38. Zhao, D.; Candish, L.; Paul, D.; Glorius, F. N-heterocyclic carbenes in asymmetric hydrogenation. ACS Catal. 2016, 6, 5978-5988. [CrossRef]

39. Janssen-Müller, D.; Schlepphorst, C.; Glorius, F. Privileged chiral N-heterocyclic carbene ligands for asymmetric transition-metal catalysis. Chem. Soc. Rev. 2017, 46, 4845-4854. [CrossRef] [PubMed]

40. Hillier, A.C.; Lee, H.M.; Stevens, E.D.; Nolan, S.P. Cationic iridium complexes bearing imidazol-2-ylidene ligands as transfer hydrogenation catalysts. Organometallics 2001, 20, 4246-4252. [CrossRef]

41. Albrecht, M.; Crabtree, R.H.; Mata, J.; Peris, E. Chelating bis-carbene rhodium(III) complexes in transfer hydrogenation of ketones and imines. Chem. Commun. 2002, 2, 32-33. [CrossRef]

42. Poyatos, M.; Mata, J.A.; Falomir, E.; Crabtree, R.H.; Peris, E. New ruthenium(II) cnc-pincer bis(carbene) complexes: Synthesis and catalytic activity. Organometallics 2003, 22, 1110-1114. [CrossRef]

43. Cross, W.B.; Daly, C.G.; Boutadla, Y.; Singh, K. Variable coordination of amine functionalised N-heterocyclic carbene ligands to $\mathrm{Ru}, \mathrm{Rh}$ and Ir: C-H and N-H activation and catalytic transfer hydrogenation. Dalton Trans. 2011, 40, 9722. [CrossRef] 
44. Seo, H.; Kim, B.Y.; Lee, J.H.; Park, H.J.; Son, S.U.; Chung, Y.K. Synthesis of chiral ferrocenyl imidazolium salts and their rhodium(I) and iridium(I) complexes. Organometallics 2003, 22, 4783-4791. [CrossRef]

45. Herrmann, W.A.; Baskakov, D.; Herdtweck, E.; Hoffmann, S.D.; Bunlaksananusorn, T.; Rampf, F.; Rodefeld, L. Chiral Nheterocyclic carbene ligands derived from $2,2^{\prime}$-bipiperidine and partially reduced biisoquinoline: Rhodium and iridium complexes in asymmetric catalysis. Organometallics 2006, 25, 2449-2456. [CrossRef]

46. Dyson, G.; Frison, J.C.; Whitwood, A.C.; Douthwaite, R.E. Synthesis of rhodium(I) and iridium(I) complexes of chiral Nheterocyclic carbenes and their application to asymmetric transfer hydrogenation. Dalton Trans. 2009, 7141. [CrossRef]

47. Diez, C.; Nagel, U. Chiral iridium(I) bis(NHC) complexes as catalysts for asymmetric transfer hydrogenation. Appl. Organomet. Chem. 2010, 24, 509-516. [CrossRef]

48. Chiyojima, H.; Sakaguchi, S. Iridium complex bearing a chiral hydroxy-amide functionalized N-heterocyclic carbene: A catalyst precursor for asymmetric transfer hydrogenation. Tetrahedron Lett. 2011, 52, 6788-6791. [CrossRef]

49. Sabater, S.; Baya, M.; Mata, J.A. Highly active cp*Ir catalyst at low temperatures bearing an N-heterocyclic carbene ligand and a chelated primary benzylamine in transfer hydrogenation. Organometallics 2014, 33, 6830-6839. [CrossRef]

50. Ramasamy, B.; Kumar Gangwar, M.; Ghosh, P. Chiral oxazolidine-fused N-heterocyclic carbene complexes of rhodium and iridium and their utility in the asymmetric transfer hydrogenation of ketones. Eur. J. Inorg. Chem. 2017, 2017, 3253-3268. [CrossRef]

51. Iglesias, M.; Oro, L.A. A leap forward in iridium-NHC catalysis: New horizons and mechanistic insights. Chem. Soc. Rev. 2018, 47, 2772-2808. [CrossRef]

52. Ramasamy, B.; Gangwar, M.K.; Ghosh, P. Asymmetric transfer hydrogenation of $\alpha, \beta$-unsaturated carbonyl compounds to saturated alcohols as catalyzed by iridium complexes of tricyclic bioxazoline-fused imidazole-derived N-heterocyclic carbene ligands. ChemistrySelect 2019, 4, 357-365. [CrossRef]

53. Yoshida, K.; Kamimura, T.; Kuwabara, H.; Yanagisawa, A. Chiral bicyclic NHC/Ir complexes for catalytic asymmetric transfer hydrogenation of ketones. Chem. Commun. 2015, 51, 15442-15445. [CrossRef]

54. CrysAlisPRO; Oxford Diffraction/Agilent Technologies UK Ltd.: Yarnton, UK, 2018.

55. Sheldrick, G.M. SHELXT_-Integrated space-group and crystal-structure determination. Acta Crystallogr. Sect. A Found. Adv. 2015, 71,3-8. [CrossRef] [PubMed]

56. Sheldrick, G.M. Crystal structure refinement with SHELXL. Acta Crystallogr. Sect. C Struct. Chem. 2015, 71, 3-8. [CrossRef] [PubMed]

57. Dolomanov, O.V.; Bourhis, L.J.; Gildea, R.J.; Howard, J.A.K.; Puschmann, H. OLEX2: A complete structure solution, refinement and analysis program. J. Appl. Crystallogr. 2009, 42, 339-341. [CrossRef]

58. Groom, C.R.; Bruno, I.J.; Lightfoot, M.P.; Ward, S.C. The Cambridge Structural Database. Acta Crystallogr. Sect. B Struct. Sci. Cryst. Eng. Mater. 2016, 72, 171-179. [CrossRef] [PubMed]

59. Bruno, I.J.; Cole, J.C.; Edgington, P.R.; Kessler, M.; Macrae, C.F.; McCabe, P.; Pearson, J.; Taylor, R. New software for searching the Cambridge Structural Database and visualizing crystal structures. Acta Crystallogr. Sect. B Struct. Sci. 2002, 58, 389-397. [CrossRef] [PubMed]

60. Macrae, C.F.; Edgington, P.R.; McCabe, P.; Pidcock, E.; Shields, G.P.; Taylor, R.; Towler, M.; van de Streek, J. Mercury: Visualization and analysis of crystal structures. J. Appl. Crystallogr. 2006, 39, 453-457. [CrossRef]

61. Macrae, C.F.; Bruno, I.J.; Chisholm, J.A.; Edgington, P.R.; McCabe, P.; Pidcock, E.; Rodriguez-Monge, L.; Taylor, R.; van de Streek, J.; Wood, P.A. Mercury CSD 2.0-New features for the visualization and investigation of crystal structures. J. Appl. Crystallogr. 2008, 41, 466-470. [CrossRef]

62. Gardner, S.; Kawamoto, T.; Curran, D.P. Synthesis of 1,3-Dialkylimidazol-2-ylidene Boranes from 1,3-Dialkylimidazolium Iodides and Sodium Borohydride. J. Org. Chem. 2015, 80, 9794-9797. [CrossRef]

63. Huang, S.; Qi, X.; Liu, T.; Wang, K.; Zhang, W.; Li, J.; Zhang, Q. Towards Safer Rocket Fuels: Hypergolic Imidazolylidene-Borane Compounds as Replacements for Hydrazine Derivatives. Chem. A Eur. J. 2016, 22, 10187-10193. [CrossRef] [PubMed]

64. Baghurst, D.R.; Michael, D.; Mingos, P.; Watson, M.J. Application of microwave dielectric loss heating effects for the rapid and convenient synthesis of organometallic compounds. J. Organomet. Chem. 1989, 368, C43-C45. [CrossRef]

65. Bernier, C.M.; DuChane, C.M.; Merola, J.S. Crystal structures of ( $\eta 4$-cycloocta-1,5-diene)bis(1,3-dimethylimidazol-2ylidene)iridium(I) iodide and ( $\eta 4$-cycloocta-1,5-diene)bis(1,3-diethylimidazol-2-ylidene)iridium(I) iodide. Acta Crystallogr. Sect. E Crystallogr. Commun. 2020, 76, 611-614. [CrossRef] [PubMed] 